\title{
N-Aryl-6-methoxy-1,2,3,4-tetrahydroquinolines: a Novel Class of Antitumor Agents Targeting the Colchicine Site on Tubulin
}

\author{
Xiao-Feng Wang ${ }^{\dagger}, \#$, Sheng-Biao Wang ${ }^{\dagger}$, Emika Ohkoshi ${ }^{\ddagger}$, Li-Ting Wang ${ }^{\ddagger}$, Ernest Hamel$§$, \\ Keduo Qian ${ }^{\ddagger}$, Susan L. Morris-Natschke ${ }^{\ddagger}$, Kuo-Hsiung Lee ${ }^{\ddagger, \perp}$, and Lan Xie ${ }^{*}, \dagger$ \\ †Beijing Institute of Pharmacology \& Toxicology, 27 Tai-Ping Road, Beijing, 100850, China \\ $\ddagger$ Natural Products Research Laboratories, UNC Eshelman School of Pharmacy, University of \\ North Carolina at Chapel Hill, NC 27599, USA \\ \#Pharmacy Department, Urumqi General Hospital, Lanzhou Military Region, Urumqi, 830000, \\ China \\ §screening Technologies Branch, Development Therapeutics Program, Division of Cancer \\ Treatment and Diagnosis, National Cancer Institute, Frederick National Laboratory for Cancer \\ Research, National Institutes of Health, Frederick, Maryland 21702, USA \\ ${ }^{\perp}$ Chinese Medicine Research and Development Center, China Medical University and Hospital, \\ Taichung, Taiwan
}

\begin{abstract}
Structural optimizations of the prior lead 1a led to the discovery of a series of $N$-aryl-6methoxy-1,2,3,4-tetrahydroquinoline derivatives as a novel class of tubulin polymerization inhibitors targeted at the colchicine binding site. The most active compound $\mathbf{6 d}$ showed extremely high cytotoxicity against a human tumor cell line panel (A549, KB, KBvin, and DU145) with $\mathrm{GI}_{50}$ values ranging from 1.5 to $1.7 \mathrm{nM}$, significantly more potent than paclitaxel, especially against the drug-resistant KBvin cell line, in the same assays. Analogues $\mathbf{5 f}, \mathbf{6 b}, \mathbf{6 c}$, and $\mathbf{6 e}$ were also quite potent, with a $\mathrm{GI}_{50}$ range of $0.011-0.19 \mu \mathrm{M}$. In further studies, active compounds $\mathbf{6 b - 6 e}$ and $\mathbf{5 f}$ significantly inhibited tubulin assembly, with $\mathrm{IC}_{50}$ values of 0.92 to $1.0 \mu \mathrm{M}$ and strongly inhibited colchicine binding to tubulin, with inhibition rates of 75-99\% (at $5 \mu \mathrm{M}$ ), comparable with or more potent than combretastatin A-4 ( $\left.\mathrm{IC}_{50} 0.96 \mu \mathrm{M}\right)$. Current studies included design, synthesis, and biological evaluations of 24 new compounds (series 3-6). Related SAR analysis, molecular modeling, and evaluation of essential drug-like properties, i.e. water solubility, $\log \mathrm{P}$, and in vitro metabolic stability, were also performed.
\end{abstract}

\section{Keywords}

$N$-aryl-6-methoxy-1,2,3,4-tetrahydroquinolines; cytotoxicity; tubulin polymerization inhibitors; colchicine binding site

\footnotetext{
(c) 2013 Elsevier Masson SAS. All rights reserved.

*Corresponding author. Tel/fax: +86 10 6931690. lanxieshi@yahoo.com (L. Xie)..
}

Publisher's Disclaimer: This is a PDF file of an unedited manuscript that has been accepted for publication. As a service to our customers we are providing this early version of the manuscript. The manuscript will undergo copyediting, typesetting, and review of the resulting proof before it is published in its final citable form. Please note that during the production process errors may be discovered which could affect the content, and all legal disclaimers that apply to the journal pertain. 


\section{Introduction}

Microtubules, formed by a dynamic polymerization and depolymerization of $\alpha$ - and $\beta$ tubulin heterodimers, play important roles in cellular activities [1]. For many years, certain drugs that bind to the taxol or vinca site on tubulin, such as paclitaxel and vinblastine, have been widely used in the clinic to treat cancers [2]. However, their narrow therapeutic windows and the emergence of drug resistance have encouraged continued efforts to discover safer and more effective agents capable of treating resistant cancer phenotypes. Another natural product colchicine (Figure 1) binds to a unique site on tubulin, distinct from the above two binding sites, and_can effectively inhibit tubulin assembly. Even though colchicine is not used clinically because of its high toxicity, other small molecules bind at the colchicine site, e.g., $N$-deacetyl- $N$-(2-mercaptoacetyl)-colchicine (DAMA-colchicine) and combretastatin A-4 (CA-4), and some have exhibited high potency, lower toxicity, and greater efficacy against cancers resistant to existing tubulin-targeting drugs [3]. More attractively, some of these compounds exhibit a vascular disrupting effect on vascular endothelial cells and have entered into clinical development as vascular disrupting agents (VDAs) for cancer treatment. Examples of this novel class of anticancer agents are CA-4P and ZD6126 (Figure 1) [4,5].

In our prior studies on new anticancer agents [6,7], we discovered methyl 6-chloro-2-( $N$-(4methoxyphenyl)- $N$-methyl)aminonicotinate (1a, Figure 2 ) as a lead compound with potent cytotoxic activity $\left(\mathrm{GI}_{50} 0.20-0.26 \mu \mathrm{M}\right)$ against A549, KB, KBvin, and DU145 human tumor cell lines. Its biological target was identified as tubulin, specifically the colchicine site. Previous related SAR studies indicated that a para-methoxyphenyl moiety (B-ring) is an essential pharmacophore, that a tertiary amine linker can provide a feasible binding conformation, and that the substituted pyridine ring (A-ring) can be modified to improve potency. Based on these known SAR findings, we pursued optimization of lead 1a, following the strategies shown in Figure 2, to identify additional tubulin inhibitors with new scaffolds and high potency. Because the $o$-chloropyridine moiety could potentially lead to metabolic toxicity resulting from in vivo nucleophilic replacement [8], we initially replaced the pyridine ring (A-ring) of $\mathbf{1 a}$ with a benzene ring and also changed the identities and positions of substituents $\mathrm{R}^{1}$ and $\mathrm{X}$ on the A-ring (series 3-4 compounds) to investigate how these modifications impacted inhibitory activity against tumor cell growth. Previously, we also postulated that the degree of torsional angle between the two aryl rings (A- and B-rings) might be crucial for activity; therefore, our next modification focused on the $N$-linkage. By applying a conformation restriction strategy [9], we connected a propyl group on the $\mathrm{N}$ linker to the neighboring benzene ring (B-ring) to form a six-membered fused tetrahydropyridine ring (series $\mathbf{5}$ compounds). By constraining the flexible conformation, we could better explore feasible binding conformations and possible ligand-target interactions. We next postulated that introducing a fused aromatic ring onto the A-ring might make the molecular binding conformation of new series $\mathbf{6}$ compounds more similar to that of colchicine and enhance affinity with the binding site on tubulin, leading to better antitumor activity. All newly synthesized compounds were evaluated by cellular screening against a human tumor cell line (HTCL) panel, and selected potent compounds were also assayed for tubulin inhibition. Molecular modeling was used to illustrate the interaction between tubulin and the new ligand(s) as well as differences among ligands. Furthermore, certain essential parameters related to drug-like properties, such as water solubility, $\log \mathrm{P}$, and metabolic stability, were determined for highly potent compounds. Chemical synthesis, biological evaluation, molecular modeling, and SAR analysis are presented in this paper. 


\section{Chemistry}

The syntheses of target compounds 3-6 are outlined in Schemes 1 and 2. Intermediate 2a was prepared by Ullmann condensation reaction [10] of commercially available 4methoxyaniline and 2,4-dichlorobenzoic acid in the presence of $\mathrm{Cu} / \mathrm{Cu}_{2} \mathrm{O}$ in 2ethoxyethanol, following esterification with DMF-DMA (two equivalents) in toluene at reflux for $24 \mathrm{~h}$. Intermediates $\mathbf{2 b - d}$ were obtained by a Buchwald-Hartwig coupling reaction between 4-methoxyaniline and methyl 5-substituted-3-bromo (or iodo) benzoate in the presence of catalyst $\mathrm{Pd}(\mathrm{OAc})_{2}$ and $\mathrm{Cs}_{2} \mathrm{CO}_{3}$ either with $\mathrm{X}$-phos [11] under microwave (mw) irradiation at $120-150^{\circ} \mathrm{C}$ (Method A for $\mathbf{2 b}$ and $\mathbf{2 c}$ ) or with BINAP and traditional heating in toluene at reflux under nitrogen protection (Method B for 2d). Subsequently, secondary amines 2a-d were treated with methyl iodide in the presence of sodium hydride to afford corresponding tertiary diarylamines 3a and 4a-c. When using $\mathrm{LiAlH}_{4}$ in $\mathrm{THF}$ at $0{ }^{\circ} \mathrm{C}$ for $1 \mathrm{~h}$, the ester group of $\mathbf{3 a}$ was reduced to a hydroxymethyl moiety, affording $\mathbf{3 b}$ in nearly quantitative yield. Compound $\mathbf{3 b}$ was further methylated with methyl iodide to give ether $\mathbf{3 c}$. Alternatively, the ester group in 3a and 4a-c was converted to an $N$-methylcarbamoyl group by treatment with methylamine in $\mathrm{MeOH}$ under mw irradiation at $100-120{ }^{\circ} \mathrm{C}$ to produce corresponding compounds $\mathbf{3 d}$ and $\mathbf{4 d - f}$, respectively, in high yields (79-89\%). Methylation of $\mathbf{4 f}$ with methyl iodide yielded compound $\mathbf{4 g}$ with a $N, N$-dimethylcarbamoyl group on the A-ring. Ester compound $\mathbf{4} \mathbf{c}$ was hydrolyzed under basic conditions to produce carboxylic acid compound $\mathbf{4 h}$. Compound $\mathbf{4 h}$ was then treated with 1-hydroxybenzotriazole (HOBt) in the presence of 1-ethyl-3-(3-dimethylaminopropyl)carbodiimide (EDCI) hydrochloride salt, followed by reaction with cyclopropylamine or cyclopentylamine to produce corresponding $N$-cyclopropylamide and $N$-cyclopentylamide compounds $\mathbf{4 i}$ and $\mathbf{4 j}$, respectively [12]. By using Buchwald-Hartwig coupling reactions and the same conditions, compounds $\mathbf{5 a - 5 b}$ and 6a-6b were synthesized from intermediate 6-methoxy-1,2,3,4-tetrahydroquinoline (7) [13] and an aryl halide, such as phenyl, naphthyl, and quinolyl halides, in $68-75 \%$ yields. Similarly to series $\mathbf{3}$ and $\mathbf{4}$, the ester group in $\mathbf{5 a}$ and $\mathbf{5 b}$ was converted into an $N$-alkyl carbamoyl or carboxy group to provide corresponding compounds $\mathbf{5 c - f}$ by using the same methods described above. Differently from $\mathbf{6 a}$ and $\mathbf{6 b}$, the preparation of $\mathbf{6 c}$ and $\mathbf{6 d}$ involved coupling 7 with a 2-substituted 4-haloquinazoline under EtOH reflux in the presence of $\mathrm{NaHCO}_{3}$, resulting in $79-87 \%$ yields. Using the same method for preparing $\mathbf{5 c}$, compound 6d was converted to 6e. All new series 3-6 compounds were identified by ${ }^{1} \mathrm{H}$ NMR and MS spectroscopic data, with purity determined by HPLC.

\section{Results and Discussion}

\subsection{Evaluation of Cytotoxicity and Tubulin Inhibition Activity in Vitro}

The 24 newly synthesized tertiary arylamines (series 3-6) were evaluated in cellular cytotoxicity assays against a HTCL panel, including A549 (lung carcinoma), KB (epidermoid carcinoma of the mouth), KBvin, a P-gp-expressing multidrug-resistant cell line (vincristine-resistant KB)[14, 15], and DU145 (prostate cancer) with paclitaxel as a reference compound. The in vitro anticancer activity $\left(\mathrm{GI}_{50}\right)$ was determined using the established sulforhodamine B (SRB) method [16]. The cytotoxicity data of all new compounds in HTCL assays are listed in Tables 1 and 2. Subsequently, selected compounds with high potency in cellular assays were further tested in tubulin assays to determine biological target and binding site.

In series 3 compounds with a phenyl A-ring and substituent $\mathrm{X}$ equal to $m$-chloro, two compounds $3 \mathbf{a}\left(\mathrm{R}^{1}=o\right.$-COOMe $)$ and $\mathbf{3} \mathbf{c}\left(\mathrm{R}^{1}=o-\mathrm{CH}_{2} \mathrm{OMe}\right)$ showed promising potency with low micromolar $\mathrm{GI}_{50}$ values of 1.68 to $5.24 \mu \mathrm{M}$, indicating that replacement of the pyridine A-ring in lead 1a is tolerated and $\mathrm{R}^{1}$ on the A-ring is modifiable. When the COOMe group 
$\left(\mathrm{R}^{1}\right)$ was moved to the meta-position on the A-ring, the resulting compound $\mathbf{4 a}$ exhibited somewhat improved activity $\left(\mathrm{GI}_{50} 1.46-1.61 \mu \mathrm{M}\right)$ compared with $\mathbf{3 a}\left(\mathrm{R}^{1}=\sigma\right.$-COOMe, $\mathrm{GI}_{50}$ $1.68-3.36 \mu \mathrm{M})$. This finding prompted us to synthesize compounds $\mathbf{4 b - f}$, in which the meta$\mathrm{R}^{1}$ was either maintained as an ester (COOMe) or changed to a $N$-methylcarbamoyl (CONHMe) group, while substituent $\mathrm{X}$ was present as either a chloro, trifluoromethyl or bromo group. Interestingly, compounds $\mathbf{4 a}, \mathbf{4 c}, \mathbf{4 d}$, and $\mathbf{4 f}$ where $\mathrm{X}$ is either chloride or bromide were more potent than 3a. In addition, compounds $4 \mathbf{d}$ and $\mathbf{4 f}$ with a meta- $N$ methylcarbamoyl group $\left(\mathrm{R}^{1}\right)$ showed significantly improved potency with a $\mathrm{GI}_{50}$ range of $0.14-0.30 \mu \mathrm{M}$, compared with related meta-ester compounds $\mathbf{4 a}$ and $\mathbf{4 c}$. In contrast, $\mathbf{4 b}$ and 4e with a trifluoromethyl $(\mathrm{X})$ group were less active than corresponding chloro- and bromocompounds in the same assays, Next, the cytotoxicity results for bromo-substituted compounds $\mathbf{4 g - j}$ revealed the impact of the $m$-alkanoyl group $\left(\mathrm{R}^{1}\right)$. When the meta- $N$ methylcarbamoyl (4f) or meta-ester $(\mathbf{4 c})$ was converted to a more bulky $\mathrm{N}, \mathrm{N}$ dimethylcarbamoyl $(\mathbf{4 g})$ or more polar carboxy (4f) group, potency decreased or was abolished completely, respectively. But when $\mathrm{R}^{1}$ was an $N$-cyclopropylcarbamoyl or $N$ cyclopentylcarbamoyl group, the corresponding compounds $\mathbf{4 i}$ and $\mathbf{4} \mathbf{j}$ showed improved potency with $\mathrm{GI}_{50}$ values of 0.11 to $0.17 \mu \mathrm{M}$, more potent than the other series $\mathbf{3}$ and $\mathbf{4}$ compounds, as well as 1a. Because corresponding series $\mathbf{4}$ compounds (4a, $\mathbf{4 d})$ were more potent than series $\mathbf{3}$ compounds ( $\mathbf{3 a}, \mathbf{3 d}$ ), we postulated that the meta-substitution on the Aring might favor an appropriate torsional angle between the two aromatic rings, due to decreased steric hindrance around the $N$-linker, which would be consistent with our prior hypothesis. Moreover, the high potency of $\mathbf{4 d}, \mathbf{4 f}, \mathbf{4 i}$, and $\mathbf{4 j}$ demonstrated that a hydrophobic meta- $N$-alkylcarbamoyl group with a suitable volume could enhance antitumor potency.

When the $N$-linker between the A- and B-rings was incorporated into a six-membered 1,2,3,4-tetrahydropyridine ring fused with the B-ring, all five compounds 5a-d,f exhibited high cytotoxicity with $\mathrm{GI}_{50}$ values of 0.15 to $2.33 \mu \mathrm{M}$ (Table 1). Thus, the ring-restricted $N$ linker was favorable for cytotoxic activity. Consequently, all series 6 compounds contain a 6-methoxy-1,2,3,4-tetrahydroquinoline moiety connected to an aromatic (naphthalene) or heteroaromatic (quinoline or quinazoline) bicyclic ring system, in which the resonance system of the A-ring is extended over an additional fused aromatic ring. As shown in Table 2 , except for $\mathbf{6 a}$ with a naphthyl A-ring system, compounds with either a quinoline (6b) or quinazoline (6c-6e) moiety exhibited extremely high cytotoxicity in the HTCL assays. Among them, 6d with a 2-chloroquinazoline moiety (A-ring) was the most potent with $\mathrm{GI}_{50}$ values ranging from 1.5 to $1.7 \mathrm{nM}$. Thus, $\mathbf{6 d}$ was more potent than paclitaxel in the same assays, especially against the drug-resistant $\mathrm{KBvin}$ cell line $\left(\mathrm{GI}_{50} 0.0017 \mu \mathrm{M}\right.$ versus 1.21 $\mu \mathrm{M}$, respectively). Compounds $\mathbf{6 b}$ (2-methylquinoline), $\mathbf{6 c}$ (2-methylquinazoline), and $\mathbf{6 e}$ (2-methylaminoquinazoline) also showed high cytotoxicity with a $\mathrm{GI}_{50}$ range of $11-91 \mathrm{nM}$, more potent by at least ten-fold than 1a and series 3-5 compounds. Similarly to $\mathbf{6 d}$, analogs $\mathbf{6 b}, \mathbf{6 c}$, and $\mathbf{6 e}$ were also much more potent than paclitaxel against KBvin cell growth, indicating that this compound type has great potential to overcome resistance to paclitaxel.

Based on these results in cellular assays, active compounds $4 \mathbf{f}, \mathbf{4 i}, \mathbf{5 f}$, and $\mathbf{6 b - e}\left(\mathrm{GI}_{50}<1\right.$ $\mu \mathrm{M})$ were evaluated in tubulin inhibition assays, in parallel with CA-4, a drug candidate in clinical trials, as a reference. As shown in Table 3, while $N$-methyl linked compounds $\mathbf{4 f}$ and $4 \mathbf{i}$ (open $N$-linker) showed good inhibitory potency against tubulin assembly $\left(\mathrm{IC}_{50} 1.6-2.2\right.$ $\mu \mathrm{M}$ ), the $\mathrm{N}$-phenyl-6-methoxy-1,2,3,4-tetrahydroquinoline compound $\mathbf{5 f}$ (ring-restricted $\mathrm{N}$ linker) exhibited improved potency in both tubulin assembly $\left(\mathrm{IC}_{50} 1.0 \mu \mathrm{M}\right)$ and colchicine binding $(75 \%)$ assays. Thus, the presence of the ring-restricted $N$-linker probably increases compound affinity for tubulin. Furthermore, $\mathbf{6 b}$-e with both a ring-restricted $N$-linker and a fused bicyclic aromatic ring system (A-ring) also displayed high potency in the tubulin 
assembly ( $\left.\mathrm{IC}_{50} 0.92-1.00 \mu \mathrm{M}\right)$ and inhibition of colchicine binding $(87-99 \%$ at $5 \mu \mathrm{M}$ and $61-95 \%$ at $1 \mu \mathrm{M})$ assays, comparable with and greater than those of $\mathbf{5 f}$, respectively. Consistent with the cellular assays, compound $\mathbf{6 d}$ was the most potent compound with an $\mathrm{IC}_{50}$ value of $0.93 \mu \mathrm{M}$ against tubulin assembly and inhibitory rates of $99 \%$ and $95 \%$ at 5 $\mu \mathrm{M}$ and $1 \mu \mathrm{M}$, respectively, for competitively inhibiting colchicine binding to tubulin. These data are comparable or better than those for the reference compound CA-4 $\left(\mathrm{IC}_{50} 0.96 \mu \mathrm{M}\right.$, 98\% and $90 \%$ respectively). Thus, $N$-aryl-6-methoxy-1,2,3,4-tetrahydroquinoline compounds, e.g., series 5-6, likely present a novel class of highly potent tubulin polymerization inhibitors targeted at the colchicine binding site. Meanwhile, we postulated that a fused bicyclic aromatic A-ring might interact with the colchicine site in some way, possibly resulting in increased affinity for tubulin. On the other hand, the active $\mathbf{6}$ series compounds might also interact with other unidentified target(s), because $\mathbf{6 b}-\mathbf{e}$ displayed much higher potency than $\mathbf{5 f}$ in the cellular cytotoxicity assays, but similar inhibitory activity against tubulin polymerization.

\subsection{Molecular Modeling}

To better understand interactions between the newly synthesized active inhibitors and tubulin, we investigated potential binding modes of active compounds $\mathbf{4 i}, \mathbf{5 f}$, and $\mathbf{6 d}$ at the colchicine site in the tubulin dimer by using the CDOCKER program in the Discovery Studio 3.0 software with the tubulin crystal structure (PDB: 1SA0) [17,18], as in our previous study. In the binding models shown in Figure 3A, both $\mathbf{4 i}$ (purple) and $\mathbf{5 f}$ (green) displayed low energy binding conformations ( -30.58 and $-33.31 \mathrm{kcal} / \mathrm{mol}$, respectively) that superimposed well with each other and with DAMA-colchicine (cyan), the ligand used in the tubulin crystal structure. As seen in Figure 3A, a hydrogen bond is present between Val181 in the a-T5 loop of tubulin and the amide carbonyl group on the A ring of $\mathbf{4 i}$ and $\mathbf{5 f}$. This hydrogen bond is also observed between Val181 and the carbonyl group on the C-ring of DAMA-colchicine. In addition, the $N$-cyclopropyl of the amide group in both $\mathbf{4 i}$ and $\mathbf{5 f}$ overlaps with the methoxy group on the seven-membered ring (C-ring) of DAMAcolchicine and stretches into a small lipophilic pocket around the amino acids in $\alpha-\mathrm{T} 5, \beta-\mathrm{H} 8$, $\beta$-S 8 and $\beta$-S9 of tubulin. In addition, the 4-methoxyphenyl moiety (B-ring) in $\mathbf{4 i}$ and $\mathbf{5 f}$, regardless of whether the $N$-linker is open or ring-restricted, overlaps with the trimethoxyphenyl portion of DAMA-colchicine. The $4-\mathrm{OCH}_{3}$ group on the B-ring of $\mathbf{4 i}$ and 5f forms a hydrogen bond with the Cys241 side chain in $\beta-\mathrm{H} 7$ of tubulin, and a similar interaction is also observed with the $2^{\prime}-\mathrm{OCH}_{3}$ on the A-ring of DAMA-colchicine. Cys241 is a key amino acid that interacts with most tubulin inhibitors bound at the colchicine site. In the crystal structure, the $\mathrm{C} 5$ and $\mathrm{C} 6$ atoms of the B-ring of DAMA-colchicine are involved in hydrophobic interactions with the side chains of Ala $\beta 250$ and Leuß255 in tubulin's $\beta$-H8 region. Although the $\mathrm{N}-\mathrm{CH}_{3}$ linker in $\mathbf{4 i}$ is not in close proximity to Ala $\beta 250$ and Leuß255 $(>4 \AA)$, the added carbons in the six-membered tetrahydropyridine cyclic linker in $\mathbf{5 f}$ are closer to the hydrophobic side chains of Ala 3250 and Leuß255 $(<4 \AA$ A). The additional van der Waal's force between the cyclic linker and the binding site would likely strengthen affinity of $\mathbf{5 f}$ for tubulin. Therefore, our current modeling results might explain, at least partially, the higher potency of $\mathbf{5 f}$ than $\mathbf{4 f}$ and $\mathbf{4 i}$ in the tubulin assays (Table 3).

Consistent with our earlier hypothesis [6,7], the steric hindrance of the $\mathrm{N}-\mathrm{CH}_{3}$ linker [19] results in a binding torsional angle of $74.89^{\circ}$ between the two aromatic rings in $\mathbf{4 i}$, allowing the $N$-alkyl amide group on the A-ring to interact with the binding site as described above. When the $N$-linker is connected with additional carbons into a six-membered ring, a similar torsional angle $\left(70.52^{\circ}\right)$ was found, maintaining a favorable binding conformation for $\mathbf{5 f}$ and all major interactions with the binding site as mentioned above for $4 \mathbf{i}$. Figure $3 \mathrm{~B}$ shows that $\mathbf{6 d}$ (binding energy: $-34.39 \mathrm{kcal} / \mathrm{mol}$ ) has a similar binding orientation as those of $\mathbf{4 i}$ and $\mathbf{5 f}$, as well as good superimposition with DAMA-colchicine. The major interactions of the 
B-ring and the cyclic linker with tubulin are maintained. The torsional angle $\left(69.07^{\circ}\right)$ between the two rings in $\mathbf{6 d}$ is similar to that of $\mathbf{5 f}$, resulting in a superimposition between the quinazoline ring of $\mathbf{6 d}$ and the aromatic C-ring of DAMA-colchicine. Although we postulated that the fused aromatic ring introduced in $\mathbf{6 d}$ would play a role similar to that of the C-ring of colchicine within the binding site on tubulin, no interaction was obvious in the computational model. Because of the torsional angle between the two aryl rings, the 2chloro group on the quinazoline in $\mathbf{6 d}$ [as well as the $m$-bromo group on the phenyl (A-ring) in $4 \mathbf{i}$ and $\mathbf{5 f}$ (Figure 3A)] was orientated similarly to the acetyl group on the B-ring in DAMA-colchicine. Thus, the $\mathrm{X}$ substituent on the quinazoline (or other aromatic ring system) might interact with tubulin in some way and be modifiable.

\subsection{Drug-like property evaluations}

Next, we evaluated aqueous solubility and $\log P$ parameters of $4 \mathbf{4 f}, 4 \mathbf{i}, 5 \mathbf{5 f}, \mathbf{6 b}, \mathbf{6 c}, \mathbf{6 d}$ and $\mathbf{6 e}$ as described previously [20]. As shown in Table 4, compounds $\mathbf{6 b}, \mathbf{6 c}$, and $\mathbf{6 e}$ showed much better aqueous solubility (3.21-7.67 $\mu \mathrm{g} / \mathrm{mL})$ than the other four compounds $(\square 1.0 \mu \mathrm{g} / \mathrm{mL}$ ). Consistently, $\log \mathrm{P}$ values of $\mathbf{6 b}, \mathbf{6 c}$, and 6e (1.07-3.98) were also lower (4f, 4i, 5f, 6d >4). Subsequently, metabolic stability of $\mathbf{6 b - 6 e}$ was further evaluated by an in vitro human liver microsome incubation assay with propranolol (moderate metabolism in vivo, $\mathrm{t}_{1 / 2} 3-5 \mathrm{~h}$ ) and terfenadine (fast metabolism in vivo, $\mathrm{t}_{1 / 2}<3 \mathrm{~h}$ ) as positive controls. Compounds $\mathbf{6 c}\left(\mathrm{t}_{1 / 2}\right.$ $25.19 \mathrm{~min})$ and $6 \mathbf{e}\left(\mathrm{t}_{1 / 2} 25.97 \mathrm{~min}\right)$ were more stable than terfenadine $\left(\mathrm{t}_{1 / 2} 21.14\right)$, while $6 \mathbf{b}$ and $\mathbf{6 d}$ were even less stable with short metabolic half-lives of $7.89 \mathrm{~min}$ and $10.59 \mathrm{~min}$, respectively, indicating quick metabolism. In general, a potent compound with low metabolic stability is not usually recognized as a promising drug candidate. However, compounds targeting the colchicine site of tubulin are proposed as VDAs to treat cancers. For this new type of anticancer drug candidate, rapid metabolism might be desirable to decrease drug toxicity in the body, as exemplified by ZD6126 (Fig. 1), which was developed based on this hypothesis [21].

\section{Conclusion}

Modifications of prior lead 1a resulted in the synthesis and biological evaluation of 24 new compounds (series 3-6). During this process, active compound 6d showed extremely high cytotoxicity against the screening HTCL panel with a $\mathrm{GI}_{50}$ value range of $1.5-1.7 \mathrm{nM}$, more potent than paclitaxel in the same assays, especially against resistant KBvin. Compound $\mathbf{6 d}$ also displayed significant inhibitory activity in tubulin assembly $\left(\mathrm{IC}_{50} 0.93 \mu \mathrm{M}\right)$ and colchicine binding (inhibition $99 \%$ at $5 \mu \mathrm{M}$ and $95 \%$ at $1 \mu \mathrm{M}$ ) assays, with greater potency than CA-4. Similarly, analogues $\mathbf{6 b}, \mathbf{6 c}$, and $\mathbf{6 e}$ also showed high potency in the cellular $\left(\mathrm{GI}_{50} 11-91 \mathrm{nM}\right)$ and tubulin $\left(\mathrm{IC}_{50} 0.92-1.0 \mu \mathrm{M}\right)$ assays. Therefore, $N$-aryl-6methoxy-1,2,3,4-tetrahydroquinoline derivatives were identified as a novel class of tubulin polymerization inhibitors targeted at the colchicine site. Current SAR studies lead to the following conclusions: (1) a ring-restricted $N$-linker is beneficial and provides a feasible torsional angle (about $70-75^{\circ}$ ) between the two aryl ring systems (A and B rings) for enhancing molecular affinity for tubulin; (2) the 6-methoxy-1,2,3,4-tetrahydroquinoline moiety can serve as a pharmacophore and the methoxy group on the B-ring is a necessary binding point to tubulin; (3) isosteric replacement of the A-ring is feasible and a fused aromatic ring, such as quinoline and quinazoline, improved molecular potency; (4) various $m$-substituents on the A-ring are present in active compounds, and either halogen or $\mathrm{N}$-alkyl amide/amino might be beneficial. Molecular modeling results illustrated some possible interactions of the active compounds with the colchicine site of tubulin and supported our earlier hypothesis that a feasible torsional angle between the two aryl rings might be important for high potency. An evaluation of essential drug-like properties, i.e. water solubility, $\log \mathrm{P}$, and metabolic stability in vitro, also provided useful information. These 
results will help us to develop drug candidates from this novel class of tubulin inhibitors targeted at the colchicine site in further studies.

\section{Experimental Section}

\subsection{Chemistry}

Proton and carbon nuclear magnetic resonance $\left({ }^{1} \mathrm{H}\right.$ and ${ }^{13} \mathrm{C}$ NMR $)$ spectra were measured on a JNM-ECA-400 (400 MHz) spectrometer using tetramethylsilane (TMS) as internal standard. The solvent used was $\mathrm{CDCl}_{3}$ unless otherwise indicated. Mass spectra (MS) were measured on an API-150 mass spectrometer with an electrospray ionization source from ABI, Inc. Melting points were measured by a SGW X-4 Micro-Melting point detector without correction. The mw reactions were performed on a mw reactor from Biotage, Inc. Medium- pressure column chromatography was performed using a CombiFlash ${ }^{\circledR}$ Companion system from ISCO, Inc. Thin-layer chromatography (TLC) was performed on silica gel GF254 plates. Silica gel GF254 and H (200-300 mesh) from Qingdao Haiyang Chemical Company were used for TLC and column chromatography, respectively. All commercial chemical reagents were purchased from Beijing Chemical Works or SigmaAldrich, Inc. Reagents NADPH, $\mathrm{MgCl}_{2}, \mathrm{KH}_{2} \mathrm{PO}_{4}, \mathrm{~K}_{2} \mathrm{HPO}_{4}$, and reference compounds propranolol and terfenadine were purchased from Sigma-Aldrich. HPLC grade acetonitrile for LC-MS analysis was purchased from VWR. Pooled human liver microsomes (lot no. 28831) were purchased from BD Biosciences (Woburn, MA). Purities of target compounds were determined by using an Agilent HPLC-1200 with UV detector and an Agilent Eclipse XDB-C18 column $(150 \mathrm{~mm} \times 4.6 \mathrm{~mm}, 5 \mu \mathrm{m})$, flow rate $0.8 \mathrm{~mL} / \mathrm{min}$, UV detection at 254 $\mathrm{nm}$, and injection volume of $15 \mu \mathrm{L}$. Mobile elution was conducted with a mixture of solvents A and B [Condition 1: acetonitrile (ACN)/water 60 80/40 20; Condition 2: $\mathrm{MeOH} /$ water 70 90/30 10]. For $\mathbf{6 b}, \mathbf{6 c}$ and $\mathbf{6 e}$, solvent B contained $0.025 \mathrm{mM}$ ammonium acetate.

5.1.1. Methyl 4-chloro-2-(4-methoxyphenyl)aminobenzoate (2a)-A mixture of 2,4-dichloro-benzoic acid (1.91 g, $10 \mathrm{mmol})$, 4-methoxyaniline (1.29 g, $10.5 \mathrm{mmol})$, copper powder $(58 \mathrm{mg}, 9 \% \mathrm{mmol})$, cuprous oxide $(58 \mathrm{mg}, 4 \% \mathrm{mmol})$, anhydrous potassium carbonate $(1.38 \mathrm{~g}, 10 \mathrm{mmol})$ and 2-ethoxyethanol $(7.5 \mathrm{~mL})$ was refluxed under $\mathrm{N}_{2}$ protection for $24 \mathrm{~h}$ with stirring. The mixture was poured into water and active carbon added. After filtration through Celite, the filtrate was adjusted to $\mathrm{pH} 3-4$ with aq $\mathrm{HCl}$. The collected gray solid was dried to obtain $1.85 \mathrm{~g}$ of 4-chloro-2-(4-

methoxyphenyl)aminobenzoic acid $(0.83 \mathrm{~g}, 3.0 \mathrm{mmol})$, which was methylated directly with DMF-DMA $(0.79 \mathrm{~mL}, 6.0 \mathrm{mmol})$ in toluene $(12 \mathrm{~mL})$ under reflux for $2 \mathrm{~h}$. After removal of solvent in vacuo, the residue was purified by flash column chromatography (gradient elution: EtOAc/petroleum ether, $0-30 \%$ ) to obtain $0.74 \mathrm{~g}$ of $2 \mathrm{a}$ in a $57 \%$ yield over two steps. It was used next without further purification.

5.1.2. Methyl 3-chloro-5-(4-methoxyphenylamino)benzoate (2b)-A mixture of methyl 3-chloro-5-iodobenzoate (296 mg, $1.0 \mathrm{mmol})$, 4-methoxyaniline (148 mg, 1.2 $\mathrm{mmol}), \mathrm{Cs}_{2} \mathrm{CO}_{3}$ (455 mg, $1.4 \mathrm{mmol}$ ), X-Phos (17 mg, $\left.0.04 \mathrm{mmol}\right), \mathrm{Pd}(\mathrm{OAc})_{2}(11 \mathrm{mg}, 0.05$ $\mathrm{mmol})$, Celite $(228 \mathrm{mg})$, and $t \mathrm{BuOH}(0.5 \mathrm{~mL})$ in toluene $(3 \mathrm{~mL})$ was heated at $120{ }^{\circ} \mathrm{C}$ for 1 $\mathrm{h}$ under mw irradiation with stirring. EtOAc $(10 \mathrm{~mL})$ was added to the mixture, and, after brief stirring, insoluble solid was removed by filtration. After removal of organic solvent in vacuo, the residue was purified by flash column chromatography (gradient elution: EtOAc/ petroleum ether, $0-40 \%$ ) to obtain $\mathbf{2 b}$ as a yellow solid, $216 \mathrm{mg}$, $74 \%$ yield, which was used directly in the next step without further purification. 


\subsubsection{Methyl 3-trifluoromethyl-5-(4-methoxyphenylamino)benzoate (2c)-A}

mixture of methyl 3-trifluoromethyl-5-bromobenzoate ( $285 \mathrm{mg}, 1.0 \mathrm{mmol}), 4-$ methoxyaniline (147 mg, $1.2 \mathrm{mmol}), \mathrm{Cs}_{2} \mathrm{CO}_{3}(455 \mathrm{mg}, 1.4 \mathrm{mmol}), \mathrm{X}-\mathrm{Phos}(17 \mathrm{mg}, 0.04$ $\mathrm{mmol}), \mathrm{Pd}(\mathrm{OAc})_{2}(11 \mathrm{mg}, 0.05 \mathrm{mmol})$, Celite $(228 \mathrm{mg})$, and $t$ - BuOH $(0.5 \mathrm{~mL})$ in toluene $\left(3.0 \mathrm{~mL}\right.$ ) was heated at $150{ }^{\circ} \mathrm{C}$ for 30 min under mw irradiation. After work-up as for $\mathbf{2 b}$, $240 \mathrm{mg}$ of $\mathbf{2 c}$ was obtained in $74 \%$ yield, yellow solid, which was directly used for the next step without further purification.

5.1.3. Methyl 3-bromo-5-(4-methoxyphenylamino)benzoate (2d)-A mixture of methyl 3,5-dibromobenzoate (294 mg, $1.0 \mathrm{mmol})$, 4-methoxyaniline (146 mg, $1.2 \mathrm{mmol}$ ), $\mathrm{Cs}_{2} \mathrm{CO}_{3}(455 \mathrm{mg}, 1.4 \mathrm{mmol})$, BINAP (31 mg, $\left.0.05 \mathrm{mmol}\right)$, and Pd(OAc) 2 (11 mg, 0.05 $\mathrm{mmol}$ ) in toluene $(5-10 \mathrm{~mL})$ was refluxed for $12 \mathrm{~h}$ under nitrogen protection. After the mixture was cooled to rt, EtOAc $(10 \mathrm{~mL})$ was added. After stirring, the insoluble material was removed by filtration. The solvent was removed in vacuo, and the residue was purified by flash column chromatography (gradient elution: EtOAc/petroleum ether, 0-40\%) to produce $215 \mathrm{mg}$ of $\mathbf{2 d}$ in $64 \%$ yield as a brown oil.

\subsubsection{General procedure for methylation of aniline NH with methyl iodide to} prepare 3a and 4a-c-To a solution of a diarylamine (2) and MeI (molar ratio: 1/2-3) in anhydrous DMF (ca. $3 \mathrm{~mL}$ ) was slowly added $\mathrm{NaH}$ (2-3 equiv, $60 \%$ oil suspension) at $0{ }^{\circ} \mathrm{C}$ with stirring over about $1 \mathrm{~h}$. When the reaction was completed as monitored by TLC, the mixture was poured into ice-water and extracted with EtOAc three times. The combined organic phase was washed with water and brine successively and dried over anhydrous $\mathrm{Na}_{2} \mathrm{SO}_{4}$ overnight. After removal of solvent in vacuo, the crude product was purified by flash column chromatography (gradient elution: EtOAc/petroleum ether, 0-50\%) to give the corresponding methylated tertiary amine compounds.

\subsubsection{Methyl 4-chloro-2-(N-(4-methoxyphenyl)-N-methylamino)benzoate (3a):} Starting with 2a $(670 \mathrm{mg}, 2.3 \mathrm{mmol})$, methyl iodide $(0.28 \mathrm{~mL}, 4.6 \mathrm{mmol})$ and $\mathrm{NaH}(184 \mathrm{mg}$, $4.6 \mathrm{mmol}$ ) to produce $662 \mathrm{mg}$ of $\mathbf{3 a}$ in $82 \%$ yield, yellow solid, mp $52-53{ }^{\circ} \mathrm{C} ;{ }^{1} \mathrm{H}$ NMR $\delta$ ppm $3.27\left(3 \mathrm{H}, \mathrm{s}, \mathrm{NCH}_{3}\right), 3.51\left(3 \mathrm{H}, \mathrm{s}, \mathrm{OCH}_{3}\right), 3.76\left(3 \mathrm{H}, \mathrm{s}, \mathrm{OCH}_{3}\right), 6.80\left(4 \mathrm{H}, \mathrm{m}, \mathrm{ArH}-2^{\prime}, 3^{\prime}\right.$, $\left.5^{\prime}, 6^{\prime}\right), 7.02(1 \mathrm{H}, \mathrm{dd}, J=8.4$ and $2.0 \mathrm{~Hz}, \mathrm{ArH}-5), 7.15(1 \mathrm{H}, \mathrm{d}, J=2.0 \mathrm{~Hz}, \mathrm{ArH}-3), 7.55(1 \mathrm{H}$, d, $J=8.0$, ArH-6); MS $m / z(\%) 306(\mathrm{M}+1,100), 308(\mathrm{M}+3,26)$; HPLC purity $98.3 \%$.

\subsubsection{Methyl 3-chloro-5-(N- (4-methoxyphenyl)-N-methylamino)benzoate (4a):}

Starting with $2 \mathbf{b}(322 \mathrm{mg}, 1.10 \mathrm{mmol})$, methyl iodide $(0.14 \mathrm{~mL}, 2.2 \mathrm{mmol})$ and $\mathrm{NaH}(88 \mathrm{mg}$, $2.2 \mathrm{mmol}$ ) to produce $328 \mathrm{mg}$ of $4 \mathbf{a}$ in $98 \%$ yield, yellow solid, mp 58 60 ${ }^{\circ} \mathrm{C} ;{ }^{1} \mathrm{H}$ NMR $\delta$ ppm $3.27\left(3 \mathrm{H}, \mathrm{s}, \mathrm{NCH}_{3}\right), 3.84\left(3 \mathrm{H}, \mathrm{s}, \mathrm{OCH}_{3}\right), 3.87\left(3 \mathrm{H}, \mathrm{s}, \mathrm{OCH}_{3}\right), 7.04(1 \mathrm{H}, \mathrm{t}, J=2.0 \mathrm{~Hz}$, ArH-2), $6.94\left(2 \mathrm{H}, \mathrm{d}, J=8.8 \mathrm{~Hz}, \mathrm{ArH}-2^{\prime}, 6^{\prime}\right), 7.10\left(2 \mathrm{H}, \mathrm{d}, J=8.8 \mathrm{~Hz}, \mathrm{ArH}-3^{\prime}, 5^{\prime}\right), 7.26(1 \mathrm{H}$, $\mathrm{m}, \operatorname{ArH}-4), 7.35$ (1H, t, $J=2.0 \mathrm{~Hz}, \mathrm{ArH}-6)$. MS $m / z(\%) 306(\mathrm{M}+1,39), 308(\mathrm{M}+3,13)$, 291 (100); HPLC purity $99.3 \%$.

\subsubsection{Methyl 3-trifluoromethyl-5-(N-(4-methoxyphenyl)-N-methylamino)benzoate} (4b): Starting with $2 \mathbf{c}(188 \mathrm{mg}, 0.58 \mathrm{mmol})$, methyl iodide $(0.07 \mathrm{~mL}, 1.2 \mathrm{mmol})$, and $\mathrm{NaH}$ (48 mg, $1.2 \mathrm{mmol}$ ) to produce $176 \mathrm{mg}$ of $\mathbf{4 c}$ in $89 \%$ yield, yellow oil; ${ }^{1} \mathrm{H}$ NMR $\delta \mathrm{ppm} 3.32$ $\left(3 \mathrm{H}, \mathrm{s}, \mathrm{NCH}_{3}\right), 3.85\left(3 \mathrm{H}, \mathrm{s}, \mathrm{OCH}_{3}\right), 3.90\left(3 \mathrm{H}, \mathrm{s}, \mathrm{OCH}_{3}\right), 6.95\left(2 \mathrm{H}, \mathrm{d}, J=8.8 \mathrm{~Hz}, \mathrm{ArH}-2^{\prime}, 6^{\prime}\right)$, $7.04(1 \mathrm{H}, \mathrm{s}, \mathrm{ArH}-2), 7.12\left(2 \mathrm{H}, \mathrm{d}, J=8.8 \mathrm{~Hz}, \mathrm{ArH}-3^{\prime}, 5^{\prime}\right), 7.51(1 \mathrm{H}, \mathrm{s}, \mathrm{ArH}-4), 7.61(1 \mathrm{H}, \mathrm{s}$, ArH-6). MS $m / z(\%) 340(M+1,55), 325(M-14,100)$; HPLC purity $98.7 \%$.

5.1.4.4. Methyl 3-bromo-(N-(4-methoxyphenyl)-N-methylamino)benzoate (4c): Starting with $2 \mathbf{d}(128 \mathrm{mg}, 0.38 \mathrm{mmol})$, methyl iodide $(0.07 \mathrm{~mL}, 1.1 \mathrm{mmol})$ and sodium hydride (44 $\mathrm{mg}, 1.1 \mathrm{mmol}$ ) to produce $115 \mathrm{mg}$ of $\mathbf{4 c}$ in $90 \%$ yield, yellow oil; ${ }^{1} \mathrm{H}$ NMR $\delta \mathrm{ppm} 3.27(3 \mathrm{H}$, 
s, $\left.\mathrm{NCH}_{3}\right), 3.84\left(3 \mathrm{H}, \mathrm{s}, \mathrm{OCH}_{3}\right), 3.87\left(3 \mathrm{H}, \mathrm{s}, \mathrm{OCH}_{3}\right), 6.94\left(3 \mathrm{H}, \mathrm{m}, \mathrm{ArH}-2,2^{\prime}, 6^{\prime}\right), 7.10(2 \mathrm{H}, \mathrm{d}, J$ $\left.=8.8 \mathrm{~Hz}, \mathrm{ArH}-3^{\prime}, 5^{\prime}\right), 7.29(1 \mathrm{H}, \mathrm{m}, \mathrm{ArH}-4), 7.50(1 \mathrm{H}, \mathrm{s}, \mathrm{ArH}-6) . \mathrm{MS} \mathrm{m} / \mathrm{z}(\%) 350(\mathrm{M}+1$, 34), $352(\mathrm{M}+3,29), 337(\mathrm{M}-14,100)$; HPLC purity $95.0 \%$.

\subsubsection{5-Chloro-2-hydroxymethyl-N-(4-methoxy)phenyl-N-methylaniline (3b)-A} solution of 3a (427 mg, $1.40 \mathrm{mmol})$ in THF $(4 \mathrm{~mL})$ was added dropwise to $\mathrm{LiAlH}_{4}(108 \mathrm{mg}$, $2.89 \mathrm{mmol}$, excess) in anhydrous THF $(5 \mathrm{~mL})$ at $0{ }^{\circ} \mathrm{C}$ with stirring, which was continued at the same temperature for another $1 \mathrm{~h}$. After the reaction was complete, as monitored by TLC, to the mixture was added $0.11 \mathrm{~mL}$ of water, $0.33 \mathrm{~mL}$ of $15 \%$ aq $\mathrm{NaOH}$, and $0.33 \mathrm{~mL}$ of water, successively, with stirring for another $10 \mathrm{~min}$ at $\mathrm{rt}$. Then the mixture was filtered through Celite, solvent was removed in vacuo, and the residue was purified by flash column chromatography (gradient elution: EtOAc/petroleum ether 0-40\%) to produce $377 \mathrm{mg}$ of $\mathbf{3 b}$ in $97 \%$ yield, brown oil; ${ }^{1} \mathrm{H}$ NMR $\delta \mathrm{ppm} 3.19\left(3 \mathrm{H}, \mathrm{s}, \mathrm{NCH}_{3}\right), 3.76\left(3 \mathrm{H}, \mathrm{s}, \mathrm{OCH}_{3}\right), 4.48(2 \mathrm{H}$, s, $\left.\mathrm{OCH}_{2}\right), 6.68\left(2 \mathrm{H}, \mathrm{d}, J=9.2 \mathrm{~Hz}, \mathrm{ArH}-2^{\prime}, 6^{\prime}\right), 6.79\left(2 \mathrm{H}, \mathrm{d}, J=9.2 \mathrm{~Hz}, \mathrm{ArH}-3^{\prime}, 5^{\prime}\right), 7.12(1 \mathrm{H}$, d, $J=2.0 \mathrm{~Hz}, \mathrm{ArH}-3), 7.19$ (1H, dd, $J=8.0 \& 2.0 \mathrm{~Hz}, \operatorname{ArH}-5), 7.38$ (1H, d, $J=8.0$, ArH-6). MS $m / z(\%) 278(M+1,100), 280(M+3,36)$.

\subsubsection{5-Chloro-2-(methoxymethyl)-N-(4-methoxy)phenyl-N-methylaniline (3c)}

-Prepared in the same manner as for $\mathbf{3 a}$, starting with $\mathbf{3 b}(227 \mathrm{mg}, 0.82 \mathrm{mmol})$, methyl iodide $(0.10 \mathrm{~mL}, 1.6 \mathrm{mmol})$, and $\mathrm{NaH}(66 \mathrm{mg}, 1.6 \mathrm{mmol})$ to produce $228 \mathrm{mg}$ of $3 \mathbf{c}$ in $95 \%$ yield, yellow oil; ${ }^{1} \mathrm{H}$ NMR $\delta$ ppm $3.17\left(3 \mathrm{H}, \mathrm{s}, \mathrm{NCH}_{3}\right), 3.32\left(3 \mathrm{H}, \mathrm{s}, \mathrm{OCH}_{3}\right), 3.76(3 \mathrm{H}, \mathrm{s}$, $\left.\mathrm{OCH}_{3}\right), 4.26\left(2 \mathrm{H}, \mathrm{s}, \mathrm{OCH}_{2}\right), 6.60\left(2 \mathrm{H}, \mathrm{d}, J=9.2 \mathrm{~Hz}, \mathrm{ArH}-2^{\prime}, 6^{\prime}\right), 6.79(2 \mathrm{H}, \mathrm{d}, J=9.2 \mathrm{~Hz}$, ArH-3, $\left.5^{\prime}\right), 7.11(1 \mathrm{H}, \mathrm{d}, J=2.0 \mathrm{~Hz}, \mathrm{ArH}-3), 7.20(1 \mathrm{H}, \mathrm{dd}, J=8.4 \& 2.0 \mathrm{~Hz}, \mathrm{ArH}-5), 7.45$ (1H, d, $J=8.4, \mathrm{ArH}-6)$. MS m/z (\%) $292(\mathrm{M}+1,22), 294$ (M+ 3, 7), 228 (M-63, 100).

\subsubsection{General procedure for preparing $\mathbf{N}$-methylamides $3 \mathrm{~d}, \mathbf{4 d - f}$ from esters under mw irradiation-A solution of ester compound $(0.17 \mathrm{mmol} \sim 0.40 \mathrm{mmol})$ in $3 \mathrm{~mL}$ $30 \%$ methylamine in $\mathrm{MeOH}$ was heated to $100-120{ }^{\circ} \mathrm{C}$ under mw irradiation for $1-2 \mathrm{~h}$. Then the mixture was poured into ice-water, neutralized with aq $\mathrm{HCl}(2 \mathrm{~N})$, and extracted with EtOAc three times. The combined organic phase was washed with water and brine, successively, and dried over anhydrous $\mathrm{Na}_{2} \mathrm{SO}_{4}$ overnight. After removal of solvent in vacuo, the crude product was purified by flash column chromatography (gradient elution: EtOAc/petroleum ether, 0-70\%) to give the corresponding target compound.}

5.1.7.1. N-methyl-4-chloro-2-(N-(4-methoxy)phenyl-N-methylamino)benzamide (3d): Starting with 3a $(115 \mathrm{mg}, 0.38 \mathrm{mmol})$ at $120^{\circ} \mathrm{C}$ for $2 \mathrm{~h}$ to produce $92 \mathrm{mg}$ of $\mathbf{3 d}, 79 \%$ yield, yellow oil; ${ }^{1} \mathrm{H}$ NMR $\delta$ ppm $2.89\left(3 \mathrm{H}, \mathrm{d}, J=5.2 \mathrm{~Hz}, \mathrm{NCH}_{3}\right), 3.12\left(3 \mathrm{H}, \mathrm{s}, \mathrm{NCH}_{3}\right), 3.78(3 \mathrm{H}, \mathrm{s}$, $\left.\mathrm{OCH}_{3}\right), 6.82(4 \mathrm{H}, \mathrm{m}, \mathrm{ArH}$ on the B-ring $), 7.02(1 \mathrm{H}, \mathrm{d}, J=2.0 \mathrm{~Hz}, \mathrm{ArH}-3), 7.26(1 \mathrm{H}, \mathrm{m}$, ArH-5), 8.14 (1H, d, $J=8.0$, ArH-6). MS m/z (\%) 305 (M + 1, 12) 307 (M + 3, 4), 274 (M $31,100)$.

5.1.7.2. 3-Chloro-5-(N-(4-methoxyphenyl)-N-methylamino)-N-methylbenzamide (4d): Starting with $4 \mathbf{a}(61 \mathrm{mg}, 0.20 \mathrm{mmol})$ at $100{ }^{\circ} \mathrm{C}$ for $1 \mathrm{~h}$ to produce $52 \mathrm{mg}$ of $4 \mathbf{d}, 85 \%$ yield, white solid, mp $144 \sim 145{ }^{\circ} \mathrm{C} ;{ }^{1} \mathrm{H}$ NMR $\delta$ ppm $2.96\left(3 \mathrm{H}, \mathrm{d}, J=4.8 \mathrm{~Hz}, \mathrm{NCH}_{3}\right), 3.26(3 \mathrm{H}, \mathrm{s}$, $\left.\mathrm{NCH}_{3}\right), 3.83\left(3 \mathrm{H}, \mathrm{s}, \mathrm{OCH}_{3}\right), 5.96(1 \mathrm{H}, \mathrm{s}, \mathrm{CONH}), 6.73(1 \mathrm{H}, \mathrm{s}, \mathrm{ArH}-2), 6.93(2 \mathrm{H}, \mathrm{d}, J=8.8$ $\left.\mathrm{Hz}, \mathrm{ArH}-2^{\prime}, 6^{\prime}\right), 6.96$ (1H, s, ArH-4), 6.99 (1H, s, ArH-6), 7.10 (2H, d, J=8.8 Hz, ArH-3', $\left.5^{\prime}\right)$. MS $m / z(\%) 305(\mathrm{M}+1,100), 307(\mathrm{M}+3,31)$; HPLC purity $99.3 \%$.

\subsubsection{5-(N-(4-Methoxyphenyl)-N-methylamino)-3-trifluoromethyl-N-}

methylbenzamide (4e): Starting with $4 \mathbf{b}(102 \mathrm{mg}, 0.30 \mathrm{mmol})$ at $100{ }^{\circ} \mathrm{C}$ for $1 \mathrm{~h}$ to produce $90 \mathrm{mg}$ of $4 \mathbf{e}$ in $89 \%$ yield, yellow solid, mp $115 \sim 116^{\circ} \mathrm{C} ;{ }^{1} \mathrm{H}$ NMR $\delta \mathrm{ppm} 2.99(3 \mathrm{H}, \mathrm{d}, J=$ $\left.4.8 \mathrm{~Hz}, \mathrm{NCH}_{3}\right), 3.31\left(3 \mathrm{H}, \mathrm{s}, \mathrm{NCH}_{3}\right), 3.84\left(3 \mathrm{H}, \mathrm{s}, \mathrm{OCH}_{3}\right), 6.05(1 \mathrm{H}, \mathrm{s}, \mathrm{CONH}), 6.94(2 \mathrm{H}, \mathrm{d}, J$ 
$\left.=8.8 \mathrm{~Hz}, \operatorname{ArH}-2^{\prime}, 6^{\prime}\right), 6.97(1 \mathrm{H}, \mathrm{s}, \mathrm{ArH}-2), 7.11\left(2 \mathrm{H}, \mathrm{d}, J=8.8 \mathrm{~Hz}, \operatorname{ArH}-3^{\prime}, 5^{\prime}\right), 7.20(1 \mathrm{H}, \mathrm{s}$, ArH-4), 7.26 (1H, s, ArH-6). MS m/z (\%) 339 (M + 1, 100); HPLC purity 96.3\%.

5.1.7.4. 3-Bromo-5-(N-(4-methoxyphenyl)-N-methylamino)-N-methylbenzamide (4f): Starting with $4 \mathbf{c}(100 \mathrm{mg}, 0.29 \mathrm{mmol})$ at $100{ }^{\circ} \mathrm{C}$ for $1 \mathrm{~h}$ to produce $82 \mathrm{mg}$ of $\mathbf{4 f}$ in $82 \%$ yield, white solid, mp $155 \sim 156{ }^{\circ} \mathrm{C} ;{ }^{1} \mathrm{H}$ NMR $\delta$ ppm $2.96\left(3 \mathrm{H}, \mathrm{d}, J=4.4 \mathrm{~Hz}, \mathrm{NCH}_{3}\right), 3.26(3 \mathrm{H}, \mathrm{s}$, $\left.\mathrm{NCH}_{3}\right), 3.83\left(3 \mathrm{H}, \mathrm{s}, \mathrm{OCH}_{3}\right), 5.98(1 \mathrm{H}, \mathrm{s}, \mathrm{CONH}), 6.89(1 \mathrm{H}, \mathrm{s}, \mathrm{ArH}-2), 6.93(2 \mathrm{H}, \mathrm{d}, J=8.8$ Hz, ArH-2',6'), 7.03 (1H, s, ArH-4), 7.08 (1H, s, ArH-6), 7.10 (2H, d, $J=8.8 \mathrm{~Hz}, \mathrm{ArH}-3^{\prime}$, $5)$. MS $m / z(\%) 349(\mathrm{M}+1,100), 351(\mathrm{M}+3,95)$; HPLC purity $97.9 \%$.

\subsubsection{3-Bromo-5-(N-(4-methoxyphenyl)-N-methylamino)-N,N-}

dimethylbenzamide (4g)—Prepared in the same manner as $\mathbf{3 c}$. Starting with $\mathbf{4 f} \mathbf{f}(\mathbf{7 0} \mathrm{mg}$, $0.20 \mathrm{mmol})$, methyl iodide $(0.02 \mathrm{~mL}, 0.32 \mathrm{mmol})$ and $\mathrm{NaH}(16 \mathrm{mg}, 0.40 \mathrm{mmol})$ to produce $65 \mathrm{mg}$ of $\mathbf{4 g}, 90 \%$ yield, brown solid, mp 80 81 ${ }^{\circ} \mathrm{C} ;{ }^{1} \mathrm{H}$ NMR $\delta \mathrm{ppm} 2.94\left(3 \mathrm{H}, \mathrm{s}, \mathrm{NCH}_{3}\right)$, $3.05\left(3 \mathrm{H}, \mathrm{s}, \mathrm{NCH}_{3}\right), 3.23\left(3 \mathrm{H}, \mathrm{s}, \mathrm{NCH}_{3}\right), 3.83\left(3 \mathrm{H}, \mathrm{s}, \mathrm{OCH}_{3}\right), 6.61(1 \mathrm{H}, \mathrm{dd}, J=1.2 \mathrm{~Hz}$ and $1.2 \mathrm{~Hz}, \mathrm{ArH}-4) 6.82(1 \mathrm{H}, \mathrm{m}, \mathrm{ArH}-2), 6.83(1 \mathrm{H}, \mathrm{m}, \mathrm{ArH}-6), 6.92\left(2 \mathrm{H}, \mathrm{d}, J=8.8 \mathrm{~Hz}, \mathrm{ArH}-2^{\prime}\right.$, $\left.6^{\prime}\right), 7.10\left(2 \mathrm{H}, \mathrm{d}, J=8.8 \mathrm{~Hz}, \mathrm{ArH}-3^{\prime}, 5^{\prime}\right)$. MS m/z (\%) 363 (M + 1, 100), 365 (M + 3, 95); HPLC purity $98.4 \%$.

5.1.9. 3-Bromo-5-(N-(4-methoxyphenyl)-N-methylamino)benzoic acid (4h)-To a solution of $4 \mathbf{c}(76 \mathrm{mg}, 0.20 \mathrm{mmol})$ in THF/MeOH $(2 / 2 \mathrm{~mL})$ was added aq $\mathrm{NaOH}(3 \mathrm{~N}, 2$ $\mathrm{mL}$ ), and the mixture was heated at reflux for $5 \mathrm{~h}$. After removal of solvent in vacuo, the mixture was poured into ice-water, and the insoluble solid ( $\mathrm{pH} 12)$ was removed by filtration. The filtrate was acidified to $\mathrm{pH} 2$, until there was no further precipitation. The solid was collected by filtration, washed with water until neutral, and dried to obtain $178 \mathrm{mg}$ of $\mathbf{4 h}$ in $90 \%$ yield, yellow solid, mp 242 244 ${ }^{\circ} \mathrm{C} ;{ }^{1} \mathrm{H}$ NMR (DMSO- $d_{6}$ ) $\delta \mathrm{ppm} 3.17$ (3H, s, $\left.\mathrm{NCH}_{3}\right), 3.77\left(3 \mathrm{H}, \mathrm{s}, \mathrm{OCH}_{3}\right), 7.46(1 \mathrm{H}, \mathrm{m}, \mathrm{ArH}-4), 6.97\left(2 \mathrm{H}, \mathrm{d}, J=8.8 \mathrm{~Hz}, \mathrm{ArH}-2^{\prime}, 6^{\prime}\right), 7.11$ $\left(2 \mathrm{H}, \mathrm{d}, J=8.8 \mathrm{~Hz}, \mathrm{ArH}-3^{\prime}, 5^{\prime}\right), 7.18(1 \mathrm{H}, \mathrm{d}, J=1.2 \mathrm{~Hz}, \mathrm{ArH}-6), 7.31(1 \mathrm{H}, \mathrm{s}, \mathrm{ArH}-2)$. MS m/z (\%) $336(\mathrm{M}+1,100), 338(\mathrm{M}+3,97)$.

\subsubsection{3-Bromo-5-(N-(4-methoxyphenyl)-N-methylamino)- $\mathrm{N}$ -}

cyclopropylbenzamide (4i)—A mixture of $\mathbf{4 h}$ (105 mg, $0.31 \mathrm{mmol})$, EDCI (90 mg, 0.47 $\mathrm{mmol})$, and $\mathrm{HOBt}(64 \mathrm{mg}, 0.47 \mathrm{mmol})$ in $\mathrm{CH}_{2} \mathrm{Cl}_{2}(5 \mathrm{~mL})$ was stirred at $\mathrm{rt}$ for $30 \mathrm{~min}$, and then cyclopropylamine $(27 \mathrm{mg}, 0.47 \mathrm{mmol})$ was added dropwise at $0{ }^{\circ} \mathrm{C}$ with stirring over $15 \mathrm{~min}$, followed by warming to $\mathrm{rt}$ for an additional $24 \mathrm{~h}$. The mixture was added to water $(20 \mathrm{~mL})$ and extracted with $\mathrm{CH}_{2} \mathrm{Cl}_{2}$ three times. The combined organic phase was washed with water and brine, successively, and dried over anhydrous $\mathrm{Na}_{2} \mathrm{SO}_{4}$ overnight. After removal of solvent in vacuo, crude product was purified by flash column chromatography (gradient elution: EtOAc/petroleum ether, $0-50 \%$ ) to give $95 \mathrm{mg}$ of pure $4 \mathbf{i}$ in $82 \%$ yield, white solid, mp 184-186 ${ }^{\circ} \mathrm{C} ;{ }^{1} \mathrm{H}$ NMR $\delta$ ppm $0.59\left(2 \mathrm{H}, \mathrm{m}, \mathrm{CH}_{2}\right), 0.85\left(2 \mathrm{H}, \mathrm{m}, \mathrm{CH}_{2}\right), 2.84$ $(1 \mathrm{H}, \mathrm{m}, \mathrm{CH}), 3.26\left(3 \mathrm{H}, \mathrm{s}, \mathrm{NCH}_{3}\right), 3.83\left(3 \mathrm{H}, \mathrm{s}, \mathrm{OCH}_{3}\right), 6.09(1 \mathrm{H}, \mathrm{br}, \mathrm{NH}), 6.87(1 \mathrm{H}, \mathrm{dd}, J=$ $1.6 \& 2.0 \mathrm{~Hz}, \mathrm{ArH}-2), 6.93\left(2 \mathrm{H}, \mathrm{d}, J=8.8 \mathrm{~Hz}, \mathrm{ArH}-2^{\prime}, 6^{\prime}\right), 7.05(2 \mathrm{H}, \mathrm{m}, \mathrm{ArH}-4,6), 7.09(2 \mathrm{H}$, d, $\left.J=8.8 \mathrm{~Hz}, \mathrm{ArH}-3^{\prime}, 5^{\prime}\right)$. MS m/z (\%) 375 (M + 1, 69), 377 (M + 3, 79), 320 (M - 54, 100); HPLC purity $99.1 \%$.

\subsubsection{3-Bromo-5-(N-(4-methoxyphenyl)-N-methylamino)-N-}

cyclopentylbenzamide (4j)—As for $4 \mathbf{i}$. Starting with $\mathbf{4 h}(168 \mathrm{mg}, 0.50 \mathrm{mmol})$, EDCI (144 mg, $0.75 \mathrm{mmol}$ ), HOBt (101 mg, $0.75 \mathrm{mmol}$ ), and cyclopentylamine (64 mg, 0.75 mmol) to produce $161 \mathrm{mg}$ of $\mathbf{4 j}$ in $80 \%$ yield, white solid, mp $173-174{ }^{\circ} \mathrm{C} ;{ }^{1} \mathrm{H}$ NMR $\delta$ ppm1.46 $\left(2 \mathrm{H}, \mathrm{m}, \mathrm{CH}_{2}\right), 1.69\left(4 \mathrm{H}, \mathrm{m}, 2 \times \mathrm{CH}_{2}\right), 2.08\left(2 \mathrm{H}, \mathrm{m}, \mathrm{CH}_{2}\right), 3.26\left(3 \mathrm{H}, \mathrm{s}, \mathrm{NCH}_{3}\right), 3.83$ $\left(3 \mathrm{H}, \mathrm{s}, \mathrm{OCH}_{3}\right), 4.33(1 \mathrm{H}, \mathrm{m}, \mathrm{CH}), 5.90(1 \mathrm{H}, \mathrm{br}, \mathrm{NH}), 6.86(1 \mathrm{H}, \mathrm{dd}, J=2.0$ and $2.0 \mathrm{~Hz}$, 
ArH-2), 6.93 (2H, d, $\left.J=10.0 \mathrm{~Hz}, \mathrm{ArH}-2^{\prime}, 6^{\prime}\right), 7.04$ (1H, s, ArH-4), 7.10 (3H, m, ArH-3',5', 6). MS $m / z(\%) 403(\mathrm{M}+1,100), 405(\mathrm{M}+3,91)$.

\subsubsection{N-(3-Chloro-5-carbomethoxy)phenyl-6-methoxy-1,2,3,4-} tetrahydroquinoline (5a)-Prepared in the same manner as $\mathbf{2 b}$. Starting with methyl 3chloro-5-iodobenzoate ( $297 \mathrm{mg}, 1.0 \mathrm{mmol}$ ), 6-methoxy-1,2,3,4-tetrahydroquinoline (7) (163 $\mathrm{mg}, 1.0 \mathrm{mmol}$ ) at $120{ }^{\circ} \mathrm{C}$ for $30 \mathrm{~min}$ to produce $255 \mathrm{mg}$ of $\mathbf{5 a}$ in $77 \%$ yield, yellow oil; ${ }^{1} \mathrm{H}$ NMR $\delta$ ppm $1.96\left(2 \mathrm{H}, \mathrm{m}, 3^{\prime}-\mathrm{CH}_{2}\right), 2.76\left(2 \mathrm{H}, \mathrm{t}, J=6.4 \mathrm{~Hz}, 4^{\prime}-\mathrm{CH}_{2}\right), 3.61(2 \mathrm{H}, \mathrm{t}, J=6.4 \mathrm{~Hz}$, $\left.2^{\prime}-\mathrm{CH}_{2}\right), 3.78\left(3 \mathrm{H}, \mathrm{s}, \mathrm{OCH}_{3}\right), 3.89\left(3 \mathrm{H}, \mathrm{s}, \mathrm{OCH}_{3}\right), 6.64\left(1 \mathrm{H}, \mathrm{d}, J=3.2 \mathrm{~Hz}, \mathrm{ArH}-5^{\prime}\right), 6.67$ $\left(1 \mathrm{H}, \mathrm{dd}, J=8.8 \& 3.2 \mathrm{~Hz}, \mathrm{ArH}-7^{\prime}\right), 6.96\left(1 \mathrm{H}, \mathrm{d}, J=8.8 \mathrm{~Hz}, \mathrm{ArH}-8^{\prime}\right), 7.28(1 \mathrm{H}, \mathrm{m}, \mathrm{ArH}-6)$, $7.51(1 \mathrm{H}, \mathrm{m}, \mathrm{ArH}-4), 7.66(1 \mathrm{H}, \mathrm{m}, \mathrm{ArH}-2)$. MS m/z (\%) $332(\mathrm{M}+1,100), 334(\mathrm{M}+3,30)$; HPLC purity $97.2 \%$.

\subsubsection{N-(3-Bromo-5-carbomethoxy)phenyl-6-methoxy-1,2,3,4-}

tetrahydroquinoline (5b)—Prepared in the same manner as $\mathbf{2 d}$. Starting with methyl 3,5dibromobenzoate (294 mg, $1.0 \mathrm{mmol}), 7(179 \mathrm{mg}, 1.1 \mathrm{mmol})$ for $12 \mathrm{~h}$ to produce $255 \mathrm{mg}$ of $\mathbf{5 b}$ in 68\% yield, yellow oil; ${ }^{1} \mathrm{H}$ NMR $\delta \mathrm{ppm} 1.96\left(2 \mathrm{H}, \mathrm{m}, 3^{\prime}-\mathrm{CH}_{2}\right), 2.76(2 \mathrm{H}, \mathrm{t}, J=6.4 \mathrm{~Hz}$, $\left.4^{\prime}-\mathrm{CH}_{2}\right), 3.61\left(2 \mathrm{H}, \mathrm{t}, J=6.4 \mathrm{~Hz}, 2^{\prime}-\mathrm{CH}_{2}\right), 3.78\left(3 \mathrm{H}, \mathrm{s}, \mathrm{OCH}_{3}\right), 3.89\left(3 \mathrm{H}, \mathrm{s}, \mathrm{OCH}_{3}\right), 6.65$ $\left(1 \mathrm{H}, \mathrm{dd}, J=9.2\right.$ and $\left.2.8 \mathrm{~Hz}, \mathrm{ArH}-7^{\prime}\right), 6.68\left(1 \mathrm{H}, \mathrm{d}, J=2.8 \mathrm{~Hz}, \mathrm{ArH}-5^{\prime}\right), 6.95(1 \mathrm{H}, \mathrm{d}, J=9.2$ $\left.\mathrm{Hz}, \mathrm{ArH}-8^{\prime}\right), 7.43(1 \mathrm{H}, \mathrm{t}, J=2.0 \mathrm{~Hz}, \mathrm{ArH}-4), 7.66(1 \mathrm{H}, \mathrm{t}, J=2.0 \mathrm{~Hz}, \mathrm{ArH}-6), 7.66(1 \mathrm{H}, \mathrm{m}$, ArH-2). MS m/z (\%) $376(\mathrm{M}+1,100), 378(\mathrm{M}+3,91)$.

\subsubsection{N-(3-Chloro-5-(N-methyl) carbamoyl)phenyl-6-methoxy-1,2,3,4-} tetrahydroquinoline (5c) - Prepared in the same manner as 3d. Starting with 5a (100 $\mathrm{mg}, 0.30 \mathrm{mmol}$ ) at $100{ }^{\circ} \mathrm{C}$ for $1 \mathrm{~h}$ to produce $91 \mathrm{mg}$ of $\mathbf{5 c}, 92 \%$ yield, pale yellow solid, $\mathrm{mp}$ 179 180 ${ }^{\circ} \mathrm{C} ;{ }^{1} \mathrm{H}$ NMR $\delta$ ppm $1.96\left(2 \mathrm{H}, \mathrm{m}, 3^{\prime}-\mathrm{CH}_{2}\right), 2.75\left(2 \mathrm{H}, \mathrm{t}, J=6.0 \mathrm{~Hz}, 4^{\prime}-\mathrm{CH}_{2}\right), 2.98$ $\left(3 \mathrm{H}, \mathrm{d}, J=4.8 \mathrm{~Hz}, \mathrm{NCH}_{3}\right), 3.61\left(2 \mathrm{H}, \mathrm{t}, J=6.0 \mathrm{~Hz}, 2^{\prime}-\mathrm{CH}_{2}\right), 3.78\left(3 \mathrm{H}, \mathrm{s}, \mathrm{OCH}_{3}\right), 6.05(1 \mathrm{H}$, bs, NH), 6.68 (2H, m, ArH-5 $\left.7^{\prime}\right), 6.97\left(1 \mathrm{H}, \mathrm{d}, J=8.4 \mathrm{~Hz}, \mathrm{ArH}-8^{\prime}\right), 7.17(1 \mathrm{H}, \mathrm{d}, J=1.6 \mathrm{~Hz}$, ArH-6), $7.20(1 \mathrm{H}, \mathrm{d}, J=1.6 \mathrm{~Hz}, \mathrm{ArH}-4), 7.40(1 \mathrm{H}, \mathrm{s}, \mathrm{ArH}-2)$. MS m/z (\%) $331(\mathrm{M}+1$, 100), $333(\mathrm{M}+3,32)$; HPLC purity $99.0 \%$.

\subsubsection{N-(3-Bromo-5-(N-methyl)carbamoyl)phenyl-6-methoxy-1,2,3,4-} tetrahydroquinoline (5d)—Prepared in the same manner as $\mathbf{3 d}$. Starting with $\mathbf{5 b}$ (64 $\mathrm{mg}$, $0.17 \mathrm{mmol}$ ) at $100{ }^{\circ} \mathrm{C}$ for $1 \mathrm{~h}$ to produce $57 \mathrm{mg}$ of $\mathbf{5 d}, 92 \%$ yield, white solid, $\mathrm{mp}$ $161 \sim 162{ }^{\circ} \mathrm{C} ;{ }^{1} \mathrm{H}$ NMR $\delta$ ppm $1.96\left(2 \mathrm{H}, \mathrm{m}, 3^{\prime}-\mathrm{CH}_{2}\right), 2.75\left(2 \mathrm{H}, \mathrm{t}, J=6.0 \mathrm{~Hz}, 4^{\prime}-\mathrm{CH}_{2}\right), 2.99$ $\left(3 \mathrm{H}, \mathrm{d}, J=4.8 \mathrm{~Hz}, \mathrm{NCH}_{3}\right), 3.60\left(2 \mathrm{H}, \mathrm{t}, J=6.0 \mathrm{~Hz}, 2^{\prime}-\mathrm{CH}_{2}\right), 3.78\left(3 \mathrm{H}, \mathrm{s}, \mathrm{OCH}_{3}\right), 6.02(1 \mathrm{H}$, bs, NH), $6.68\left(2 \mathrm{H}, \mathrm{m}, \mathrm{ArH}-5^{\prime}, 7^{\prime}\right), 6.96\left(1 \mathrm{H}, \mathrm{d}, J=8.4 \mathrm{~Hz}, \mathrm{ArH}-8^{\prime}\right), 7.32(1 \mathrm{H}, \mathrm{s}, \mathrm{ArH}-4), 7.36$ (1H, s, ArH-6), 7.44 (1H, s, ArH-2). MS m/z (\%) 375 (M + 1, 100), 377 (M + 3, 97); HPLC purity $98.2 \%$.

\subsubsection{N-(3-Bromo-5-carboxy)phenyl-6-methoxy-1,2,3,4-tetrahydroquinoline}

$\mathbf{5 e - P r e p a r e d ~ i n ~ t h e ~ s a m e ~ m a n n e r ~ a s ~}(\mathbf{4 h})$. Starting with $\mathbf{5 b}(226 \mathrm{mg}, 0.60 \mathrm{mmol})$ to produce $178 \mathrm{mg}$ of $\mathbf{5 e}$ in $82 \%$ yield, yellow solid, mp $176 \sim 178{ }^{\circ} \mathrm{C} ;{ }^{1} \mathrm{H}$ NMR $\delta$ ppm $1.97\left(2 \mathrm{H}, \mathrm{m}, 3^{\prime}-\right.$ $\left.\mathrm{CH}_{2}\right), 2.76\left(2 \mathrm{H}, \mathrm{t}, J=6.0 \mathrm{~Hz}, 4^{\prime}-\mathrm{CH}_{2}\right), 3.61\left(2 \mathrm{H}, \mathrm{t}, J=6.0 \mathrm{~Hz}, 2^{\prime}-\mathrm{CH}_{2}\right), 3.79\left(3 \mathrm{H}, \mathrm{s}, \mathrm{OCH}_{3}\right)$, $6.68\left(2 \mathrm{H}, \mathrm{m}, \mathrm{ArH}-5^{\prime}, 7^{\prime}\right), 6.98\left(2 \mathrm{H}, \mathrm{d}, J=8.8 \mathrm{~Hz}, \mathrm{ArH}-8^{\prime}\right), 7.48(1 \mathrm{H}, \mathrm{t}, J=2.0 \mathrm{~Hz}, \mathrm{ArH}-6)$, $7.70(1 \mathrm{H}, \mathrm{dd}, J=2.0$ and $1.6 \mathrm{~Hz}, \mathrm{ArH}-4), 7.48(1 \mathrm{H}, \mathrm{dd}, J=2.0$ and $1.6 \mathrm{~Hz}, \mathrm{ArH}-2)$. MS $m / z$ (\%) $362(\mathrm{M}+1,100), 364(\mathrm{M}+3,72)$.

\subsubsection{N-(3-Bromo-5-(N-cyclopropyl)carbamoyl)phenyl-6-methoxy-1,2,3,4-} tetrahydroquinoline $\mathbf{5 f}$-Prepared in the same manner as $\mathbf{4 i}$. Starting with $\mathbf{5 e}(109 \mathrm{mg}$, $0.30 \mathrm{mmol})$, EDCI (115 mg, $0.60 \mathrm{mmol})$, HOBt ( $81 \mathrm{mg}, 0.60 \mathrm{mmol})$, and cyclopropylamine $(56 \mathrm{mg}, 1.0 \mathrm{mmol})$ to produce $108 \mathrm{mg}$ of $\mathbf{5 f}$ in $90 \%$ yield, white solid, $\mathrm{mp} 163-164{ }^{\circ} \mathrm{C} ;{ }^{1} \mathrm{H}$ 
NMR $\delta$ ppm $0.61\left(2 \mathrm{H}, \mathrm{m}, \mathrm{CH}_{2}\right), 0.86\left(2 \mathrm{H}, \mathrm{m}, \mathrm{CH}_{2}\right), 1.95\left(2 \mathrm{H}, \mathrm{m}, 3^{\prime}-\mathrm{CH}_{2}\right), 2.75(2 \mathrm{H}, \mathrm{t}, J=$ $\left.6.4 \mathrm{~Hz}, 4^{\prime}-\mathrm{CH}_{2}\right), 2.86(1 \mathrm{H}, \mathrm{m}, \mathrm{CH}), 3.60\left(2 \mathrm{H}, \mathrm{t}, J=6.0 \mathrm{~Hz}, 2^{\prime}-\mathrm{CH}_{2}\right), 3.78\left(3 \mathrm{H}, \mathrm{s}, \mathrm{OCH}_{3}\right)$, $6.12(1 \mathrm{H}, \mathrm{br}, \mathrm{NH}), 6.66\left(2 \mathrm{H}, \mathrm{m}, \mathrm{ArH}-5^{\prime}, 7^{\prime}\right), 6.95\left(1 \mathrm{H}, \mathrm{d}, J=8.4 \mathrm{~Hz}, \mathrm{ArH}-8^{\prime}\right), 7.26(1 \mathrm{H}, \mathrm{t}, J=$ $2.0 \mathrm{~Hz}, \mathrm{ArH}-4), 7.35(1 \mathrm{H}, \mathrm{d}, J=2.0 \mathrm{~Hz}, \mathrm{ArH}-2), 7.43(1 \mathrm{H}, \mathrm{t}, J=2.0 \mathrm{~Hz}, \mathrm{ArH}-6) ;{ }^{13} \mathrm{C}$ NMR Sppm $6.91\left(\mathrm{CH}_{2}\right), 23.38(\mathrm{CH}), 23.39\left(\mathrm{CH}_{2}\right), 27.71\left(\mathrm{CH}_{2}\right), 49.78\left(\mathrm{CH}_{2}\right), 55.71\left(\mathrm{OCH}_{3}\right)$, $112.59(\mathrm{CH}), 114.35(\mathrm{CH}), 117.61(\mathrm{CH}), 120.62(\mathrm{CH}), 121.48(\mathrm{CH}), 123.02(\mathrm{C}), 125.54$ (CH), 13040 (C), 135.66 (C), 137.15 (C), 150.75 (C), 154.51 (C), 167.95 (C), 195.50 (CO). MS $m / z(\%) 401(\mathrm{M}+1,100), 403(\mathrm{M}+3,90)$; HPLC purity $98.4 \%$.

5.1.18. 6-Methoxy-N-(naphthalen-1-yl)-1,2,3,4-tetrahydroquinoline 6a-Prepared in the same manner as (2d). Starting with 1-bromonaphthalene (206 mg, $1.0 \mathrm{mmol})$ and 7 $(179 \mathrm{mg}, 1.1 \mathrm{mmol})$ for $12 \mathrm{~h}$ to produce $196 \mathrm{mg}$ of $\mathbf{6 a}$ in $68 \%$ yield, pale yellow solid, $\mathrm{mp}$ 93-95 ${ }^{\circ} \mathrm{C} ;{ }^{1} \mathrm{H}$ NMR $\delta \mathrm{ppm} 2.15\left(2 \mathrm{H}, \mathrm{br}, 3-\mathrm{CH}_{2}\right), 2.98\left(2 \mathrm{H}, \mathrm{br}, 4-\mathrm{CH}_{2}\right), 3.63(2 \mathrm{H}, \mathrm{t}, J=5.6$ $\left.\mathrm{Hz}, 2-\mathrm{CH}_{2}\right), 3.72\left(3 \mathrm{H}, \mathrm{s}, 6-\mathrm{OCH}_{3}\right), 6.06(1 \mathrm{H}, \mathrm{d}, J=8.8 \mathrm{~Hz}, \mathrm{ArH}-8), 6.41(1 \mathrm{H}, \mathrm{dd}, J=8.8$ \& $\left.2.8 \mathrm{~Hz}, \mathrm{ArH}-7), 6.68(1 \mathrm{H}, \mathrm{d}, J=2.8 \mathrm{~Hz}, \mathrm{ArH}-5), 6.97(1 \mathrm{H}, \mathrm{d}, J=7.2 \mathrm{~Hz}, \mathrm{ArH}-2)^{\prime}\right), 7.46(3 \mathrm{H}$, m, ArH-3', $\left.6^{\prime}, 7^{\prime}\right), 7.74\left(1 \mathrm{H}, \mathrm{d}, J=8.0 \mathrm{~Hz}, \mathrm{ArH}-4^{\prime}\right), 7.89\left(1 \mathrm{H}, \mathrm{d}, J=8.0 \mathrm{~Hz}, \mathrm{ArH}-5^{\prime}\right), 8.02$ $\left(1 \mathrm{H}, \mathrm{d}, J=8.0 \mathrm{~Hz}, \mathrm{ArH}-8^{\prime}\right)$. MS m/z (\%) $290(\mathrm{M}+1,100), 274$ (M-15, 100); HPLC purity $98.2 \%$.

5.1.19. 6-Methoxy-2'-methyl-3,4-dihydro-2H-1,4'-biquinoline 6b-Prepared in the same manner as (2d). Starting with 4-chloro-2-methylquinoline (178 $\mathrm{mg}, 1.0 \mathrm{mmol})$ and 7 (180 mg, $1.1 \mathrm{mmol}$ ) for $12 \mathrm{~h}$ to produce $228 \mathrm{mg}$ of $\mathbf{6 b}$ in $75 \%$ yield, yellow solid, $\mathrm{mp}$ $120 \sim 121{ }^{\circ} \mathrm{C} ;{ }^{1} \mathrm{H}$ NMR $\delta \mathrm{ppm} 2.03\left(2 \mathrm{H}, \mathrm{m}, 3-\mathrm{CH}_{2}\right), 2.65\left(3 \mathrm{H}, \mathrm{s}, 2^{\prime}-\mathrm{CH}_{3}\right), 2.94(2 \mathrm{H}, \mathrm{t}, J=6.4$ $\left.\mathrm{Hz}, 4-\mathrm{CH}_{2}\right), 3.71\left(2 \mathrm{H}, \mathrm{t}, J=5.6 \mathrm{~Hz}, 2-\mathrm{CH}_{2}\right), 3.77\left(3 \mathrm{H}, \mathrm{s}, 6-\mathrm{OCH}_{3}\right), 6.46(1 \mathrm{H}, \mathrm{d}, J=9.2 \mathrm{~Hz}$, ArH-8), $6.53(1 \mathrm{H}, \mathrm{dd}, J=9.2 \& 2.8 \mathrm{~Hz}, \mathrm{ArH}-7), 6.71(1 \mathrm{H}, \mathrm{d}, J=2.8 \mathrm{~Hz}, \mathrm{ArH}-5), 6.97(1 \mathrm{H}$, s, ArH-3'), $7.38\left(1 \mathrm{H}, \mathrm{m}, \mathrm{ArH}-6^{\prime}\right), 7.64\left(1 \mathrm{H}, \mathrm{m}, \mathrm{ArH}-7^{\prime}\right), 7.90\left(1 \mathrm{H}, \mathrm{d}, J=8.4 \mathrm{~Hz}, \mathrm{ArH}-8^{\prime}\right)$, $\left.8.01\left(1 \mathrm{H}, \mathrm{d}, J=8.4 \mathrm{~Hz}, \mathrm{ArH}-5^{\prime}\right)\right) ;{ }^{13} \mathrm{C}$ NMR $\delta$ ppm $22.41\left(\mathrm{CH}_{2}\right), 25.59\left(\mathrm{CH}_{3}\right), 27.67\left(\mathrm{CH}_{2}\right)$, $51.39\left(\mathrm{CH}_{2}\right), 55.68\left(\mathrm{OCH}_{3}\right), 112.78(\mathrm{CH}), 114.34(\mathrm{CH}), 116.44(\mathrm{CH}), 120.25(\mathrm{CH}), 123.58$ $(\mathrm{C}), 124.31(\mathrm{CH}), 124.96(\mathrm{CH}), 127.55(\mathrm{C}), 129.27(\mathrm{CH}), 129.50(\mathrm{CH}), 138.14(\mathrm{C}), 149.92$ (C), 153.93 (C), 154.75 (C), 159.78 (C). MS m/z (\%) 305 (M + 1, 100); HPLC purity $99.3 \%$.

\subsubsection{6-Methoxy-N-(2'-methylquinazol-4'-yl)-1,2,3,4-tetrahydroquinoline (6c)}

-A mixture of 4-chloro-2-methylquinazoline ( $89 \mathrm{mg}, 0.5 \mathrm{mmol}), 7$ (98 mg, $0.5 \mathrm{mmol})$, and $\mathrm{NaHCO}_{3}(126 \mathrm{mg}, 1.5 \mathrm{mmol})$ in absolute anhydrous EtOH $(5 \mathrm{~mL})$ was refluxed for $3 \mathrm{~h}$. The mixture was poured into ice-water, acidified to $\mathrm{pH} 3$ with aq $\mathrm{HCl}(2 \mathrm{~N})$, and extracted with EtOAc three times. The combined organic phases were washed with water and brine, successively, and dried over anhydrous $\mathrm{Na}_{2} \mathrm{SO}_{4}$ overnight. After removal of solvent in vacuo, the crude product was purified by flash column chromatography (gradient elution: EtOAc/petroleum ether, 0-50\%) to obtain $121 \mathrm{mg}$ of pure $\mathbf{6 c}$ in $79 \%$ yield, yellow solid, $\mathrm{mp}$ $134 \sim 136{ }^{\circ} \mathrm{C} ;{ }^{1} \mathrm{H}$ NMR $\delta \mathrm{ppm} 2.11\left(2 \mathrm{H}, \mathrm{m}, 3^{\prime}-\mathrm{CH}_{2}\right), 2.73\left(3 \mathrm{H}, \mathrm{s}, \mathrm{CH}_{3}\right), 2.88(2 \mathrm{H}, \mathrm{t}, J=6.8$ $\left.\mathrm{Hz}, 4^{\prime}-\mathrm{CH}_{2}\right), 3.79\left(3 \mathrm{H}, \mathrm{s}, \mathrm{OCH}_{3}\right), 4.05\left(2 \mathrm{H}, \mathrm{t}, J=6.8 \mathrm{~Hz}, 2^{\prime}-\mathrm{CH}_{2}\right), 6.53(1 \mathrm{H}, \mathrm{dd}, J=8.8 \&$ $\left.2.8 \mathrm{~Hz}, \mathrm{ArH}-7^{\prime}\right), 6.63\left(1 \mathrm{H}, \mathrm{d}, J=8.8 \mathrm{~Hz}, \mathrm{ArH}-8^{\prime}\right), 6.78\left(1 \mathrm{H}, \mathrm{d}, J=2.8 \mathrm{~Hz}, \mathrm{ArH}-5^{\prime}\right), 7.12$ $(1 \mathrm{H}, \mathrm{m}, \mathrm{ArH}-6), 7.32(1 \mathrm{H}, \mathrm{dd}, J=8.4 \& 1.2 \mathrm{~Hz}, \mathrm{ArH}-5), 7.62(1 \mathrm{H}, \mathrm{m}, \mathrm{ArH}-7), 7.79(1 \mathrm{H}, \mathrm{d}, J$ $=8.0 \mathrm{~Hz}, \mathrm{ArH}-8) ;{ }^{13} \mathrm{C} \mathrm{NMR} \delta \mathrm{ppm} 24.42\left(\mathrm{CH}_{2}\right), 26.65\left(\mathrm{CH}_{3}\right), 27.39\left(\mathrm{CH}_{2}\right), 47.49\left(\mathrm{CH}_{2}\right)$, $55.62\left(\mathrm{OCH}_{3}\right), 112.00(\mathrm{CH}), 113.70(\mathrm{CH}), 115.68(\mathrm{C}), 122.28(\mathrm{CH}), 124.40(\mathrm{CH}), 126.29$ $(\mathrm{CH}), 128.00(\mathrm{CH}), 132.35(\mathrm{CH}), 132.45(\mathrm{C}), 136.22(\mathrm{C}), 152.43(\mathrm{C}), 156.07(\mathrm{C}), 161.95$ (C), 163.99 (C). MS m/z (\%) $306(\mathrm{M}+1,100)$; HPLC purity $98.8 \%$.

\subsubsection{N-(2'-Chloroquinazol-4'-yl)-6-methoxy-1,2,3,4-tetrahydroquinoline (6d)}

- Similar procedure to that of $\mathbf{6 c}$. Starting with 2,4-dichloroquinazoline (200 mg, 1.0 $\mathrm{mmol}), 7(163 \mathrm{mg}, 1.0 \mathrm{mmol})$, and $\mathrm{NaHCO}_{3}(252 \mathrm{mg}, 3.0 \mathrm{mmol})$ in absolute anhydrous 
EtOH ( $8 \mathrm{~mL}$ ) for $3 \mathrm{~h}$ to produce $282 \mathrm{mg}$ of $\mathbf{6 d}$ in $87 \%$ yield, yellow solid, $\mathrm{mp}$ $136 \sim 138{ }^{\circ} \mathrm{C} ;{ }^{1} \mathrm{H}$ NMR $\delta$ ppm $2.12\left(2 \mathrm{H}, \mathrm{m}, 3^{\prime}-\mathrm{CH}_{2}\right), 2.86\left(2 \mathrm{H}, \mathrm{t}, J=6.8 \mathrm{~Hz}, 4^{\prime}-\mathrm{CH}_{2}\right), 3.81$ $\left(3 \mathrm{H}, \mathrm{s}, \mathrm{OCH}_{3}\right), 4.07\left(2 \mathrm{H}, \mathrm{t}, J=6.8 \mathrm{~Hz}, 2^{\prime}-\mathrm{CH}_{2}\right), 6.55\left(1 \mathrm{H}, \mathrm{dd}, J=8.8 \& 2.8 \mathrm{~Hz}, \mathrm{ArH}-7^{\prime}\right)$, $6.70\left(1 \mathrm{H}, \mathrm{d}, J=8.8 \mathrm{~Hz}, \mathrm{ArH}-8^{\prime}\right), 6.81\left(1 \mathrm{H}, \mathrm{d}, J=2.8 \mathrm{~Hz}, \mathrm{ArH}-5^{\prime}\right), 7.13(1 \mathrm{H}, \mathrm{m}, \mathrm{ArH}-6)$, $7.32(1 \mathrm{H}, \mathrm{dd}, J=8.8 \& 1.2 \mathrm{~Hz}, \mathrm{ArH}-5), 7.63(1 \mathrm{H}, \mathrm{m}, \mathrm{ArH}-7), 7.78(1 \mathrm{H}, \mathrm{dd}, J=8.8 \mathrm{~Hz}$ and $1.2 \mathrm{~Hz}, \mathrm{ArH}-8) ;{ }^{13} \mathrm{C} \mathrm{NMR} \delta \mathrm{ppm} 23.67\left(\mathrm{CH}_{2}\right), 26.84\left(\mathrm{CH}_{2}\right), 48.86\left(\mathrm{CH}_{2}\right), 55.78\left(\mathrm{OCH}_{3}\right)$, $112.82(\mathrm{CH}), 113.14(\mathrm{C}), 114.06(\mathrm{CH}), 123.21(\mathrm{CH}), 123.99(\mathrm{CH}), 126.68(\mathrm{CH} \times 2), 132.44$ (C), $135.44(\mathrm{CH}), 135.86(\mathrm{C}), 145.79(\mathrm{C}), 152.50(\mathrm{C}), 159.10(\mathrm{C}), 160.89$ (C). MS m/z (\%) $326(\mathrm{M}+1,100), 328(\mathrm{M}+3,31)$; HPLC purity $98.4 \%$.

\subsubsection{6-Methoxy-N-(2'-(N-methyl)aminoquinazol-4'-yl)-1,2,3,4-}

tetrahydroquinoline (6e)-Prepared in the same manner as 3d. Staring with $\mathbf{6 d}(65 \mathrm{mg}$, $0.20 \mathrm{mmol}$ ) in $3 \mathrm{~mL}$ of methylamine $(30 \%)$ was heated to $100{ }^{\circ} \mathrm{C}$ for $1 \mathrm{~h}$ to produce $42 \mathrm{mg}$ of 6e in 66\% yield, yellow solid, mp 139 140 ${ }^{\circ} \mathrm{C} ;{ }^{1} \mathrm{H}$ NMR $\delta \mathrm{ppm} 2.07\left(2 \mathrm{H}, \mathrm{m}, 3^{\prime}-\mathrm{CH}_{2}\right)$, $2.85\left(2 \mathrm{H}, \mathrm{t}, J=6.8 \mathrm{~Hz}, 4^{\prime}-\mathrm{CH}_{2}\right), 3.10\left(3 \mathrm{H}, \mathrm{d}, J=5.2 \mathrm{~Hz}, \mathrm{NCH}_{3}\right), 3.79\left(3 \mathrm{H}, \mathrm{s}, \mathrm{OCH}_{3}\right), 3.94$ $\left(2 \mathrm{H}, \mathrm{t}, J=6.8 \mathrm{~Hz}, 2^{\prime}-\mathrm{CH}_{2}\right), 6.53\left(1 \mathrm{H}, \mathrm{dd}, J=9.2 \& 2.8 \mathrm{~Hz}, \mathrm{ArH}-7^{\prime}\right), 6.67(1 \mathrm{H}, \mathrm{d}, J=9.2 \mathrm{~Hz}$, ArH-8'), $6.76\left(1 \mathrm{H}, \mathrm{d}, J=2.8 \mathrm{~Hz}, \operatorname{ArH}-5^{\prime}\right), 6.83(1 \mathrm{H}, \mathrm{m}, \operatorname{ArH}-6), 7.29(1 \mathrm{H}, \mathrm{d}, J=8.0 \mathrm{~Hz}$, ArH-5), $7.46(1 \mathrm{H}, \mathrm{m}, \mathrm{ArH}-7), 7.52(1 \mathrm{H}, \mathrm{d}, J=8.0 \mathrm{~Hz}, \mathrm{ArH}-8)$. MS m/z (\%) $321(\mathrm{M}+1$, 100); HPLC purity $98.6 \%$.

\subsection{Antiproliferative Activity Assay}

Target compounds were assayed by the SRB method for cytotoxic activity using a HTCL assay according to procedures described previously [22-24]. The panel of cell lines included human lung carcinoma (A-549), epidermoid carcinoma of the nasopharynx (KB), P-gpexpressing epidermoid carcinoma of the nasopharynx (KBvin), and prostate cancer (DU145). The cytotoxic effects of each compound were expressed as $\mathrm{GI}_{50}$ values, which represent the molar drug concentrations required to cause $50 \%$ tumor cell growth inhibition.

\subsection{Tubulin Assays}

Tubulin assembly was measured by turbidimetry at $350 \mathrm{~nm}$ as described previously [25]. Assay mixtures contained $1.0 \mathrm{mg} / \mathrm{mL}(10 \mu \mathrm{M})$ tubulin and varying compound concentrations were pre-incubated for $15 \mathrm{~min}$ at $30^{\circ} \mathrm{C}$ without guanosine $5^{\prime}$-triphosphate (GTP). The samples were placed on ice, and $0.4 \mathrm{mM}$ GTP was added. Reaction mixtures were transferred to $0{ }^{\circ} \mathrm{C}$ cuvettes, and turbidity development was followed for $20 \mathrm{~min}$ at 30 ${ }^{\circ} \mathrm{C}$ following a rapid temperature jump. Compound concentrations that inhibited increase in turbidity by $50 \%$ relative to a control sample were determined.

Inhibition of the binding of $\left[{ }^{3} \mathrm{H}\right]$ colchicine to tubulin was measured as described previously [26]. Incubation of $1.0 \mu \mathrm{M}$ tubulin with $5.0 \mu \mathrm{M}\left[{ }^{3} \mathrm{H}\right]$ colchicine and $5.0 \mu \mathrm{M}$ or $1.0 \mu \mathrm{M}$ inhibitor was for $10 \mathrm{~min}$ at $37^{\circ} \mathrm{C}$, when about $40-60 \%$ of maximum colchicine binding occurs in control samples.

\subsection{Aqueous Solubility}

Determination-Solubility was measured at $\mathrm{pH} 7.4$ by using an HPLC-UV method. Test compounds were initially dissolved in DMSO at a concentration of $1.0 \mathrm{mg} / \mathrm{mL}$. Ten microliters of this stock solution were added to $\mathrm{pH} 7.4$ phosphate buffer $(1.0 \mathrm{~mL})$ with the final DMSO concentration being $1 \%$. The mixture was stirred for $4 \mathrm{~h}$ at $\mathrm{rt}$ and then centrifuged at $3000 \mathrm{rpm}$ for $10 \mathrm{~min}$. The saturated supernatants were transferred to other vials for analysis by HPLC-UV. Each sample was performed in triplicate. For quantification, a model 1200 HPLC-UV (Agilent) system was used with an Agilent Eclipse XDB-C18 column $(150 \mathrm{~mm} \times 4.6 \mathrm{~mm}, 5 \mu \mathrm{m})$ and elution was with $50 \%-80 \% \mathrm{ACN}$ in water. The flow rate was $0.8 \mathrm{~mL} / \mathrm{min}$, and injection volume was $20 \mu \mathrm{L}$. Aqueous concentration was 
determined by comparison of the peak area of the saturated solution with a standard curve plotted peak area versus known concentrations, which were prepared by solutions of test compound in $\mathrm{ACN}$ at $50,12.5,3.13,0.78$, and $0.20 \mu \mathrm{g} / \mathrm{mL}$.

\subsection{Log P Measurement}

One to two mg of test compound was dissolved in $1.0-2.0 \mathrm{~mL}$ of $n$-octane to obtain a 1.0 $\mathrm{mg} / \mathrm{mL}$ solution. Next, the same volume of water as $n$-octane was added to each vial. The mixture was stirred at $\mathrm{rt}$ for $24 \mathrm{~h}$, and then was left without stirring overnight. The aqueous and organic phases of each mixture were transferred to separate vials for HPLC analysis. The instrument and conditions were the same as those for water solubility determinations. The $\log \mathrm{P}$ was calculated by the peak area ratio in $n$-octane and in water.

\subsection{Microsomal Stability Assay}

Stock solutions of test compounds $(1 \mathrm{mg} / \mathrm{mL})$ were prepared by dissolving the pure compound in DMSO, and the solutions were stored at $4{ }^{\circ} \mathrm{C}$. Before assay, the stock solution was diluted with ACN to $0.1 \mathrm{mM}$. For measurement of metabolic stability, all compounds were brought to a final concentration of $1 \mu \mathrm{M}$ with $0.1 \mathrm{M}$ potassium phosphate buffer at $\mathrm{pH}$ 7.4 , which contained $0.1 \mathrm{mg} / \mathrm{mL}$ human liver microsomes and $5 \mathrm{mM} \mathrm{MgCl}_{2}$. The incubation volumes were $300 \mu \mathrm{L}$, and reaction temperature was $37^{\circ} \mathrm{C}$. Reactions were started by adding $60 \mu \mathrm{L}$ of NADPH (final concentration, $1.0 \mathrm{mM}$ ) and quenched by adding $600 \mu \mathrm{L}$ of ice-cold ACN to stop the reaction at 5, 15, 30, and 60 min time points. Samples at the 0 min time point were prepared by adding $600 \mu \mathrm{L}$ of ice-cold ACN first, followed by $60 \mu \mathrm{L}$ of NADPH. All samples were prepared in duplicate. After quenching, all samples were centrifuged at $12000 \mathrm{rpm}$ for $5 \mathrm{~min}$ at $0{ }^{\circ} \mathrm{C}$. The supernatant was collected, and $20 \mu \mathrm{L}$ of the supernatant was directly injected into a Shimadzu LC-MS 2010 system with an electrospray ionization source for further analysis. The following controls were also used: (1) positive control incubation containing liver microsomes, NADPH, reference compound propranolol or terfenadine; (2) negative control incubation omitting NADPH; (3) baseline control containing only liver microsomes and NADPH. The peak heights of test compounds at different time points were converted to percentage of compound remaining, and the peak height values at initial time $(0 \mathrm{~min})$ served as $100 \%$ values. The slope of the linear regression from log percentage remaining versus incubation time relationships $(-\mathrm{k})$ was used to calculate the in vitro half-life $\left(t_{1 / 2}\right)$ by the formula of in vitro $t_{1 / 2}=0.693 / \mathrm{k}$, regarded as first-order kinetics. Conversion to in vitro $\mathrm{CL}_{\text {int }}$ (in units of $\mathrm{mL} / \mathrm{min} / \mathrm{mg}$ of protein) was calculated by the formula $\mathrm{CL}_{\text {int }}=\left[0.693 /\left(\right.\right.$ in vitro $\left.\left._{1 / 2}\right)\right][(\mathrm{mL}$ incubation $) /(\mathrm{mg}$ of microsomes)]. The HPLC-MS analysis was carried out on a Shimadzu LC-MS 2010 with an electrospray ionization source. An Alltima C18 column $(5 \mu \mathrm{m}, 150 \mathrm{~mm} \times 2.1 \mathrm{~mm})$ was used for HPLC with a gradient elution at a flow rate of $0.2 \mathrm{~mL} / \mathrm{min}$. The elution condition was $\mathrm{ACN}(\mathrm{B})$ in water (A) at $30 \%$ for $0-2 \mathrm{~min}, 85 \%$ for $2-6 \mathrm{~min}, 100 \%$ for $6-9 \mathrm{~min}$ and $30 \%$ for $9-12 \mathrm{~min}$. The MS conditions were optimized to a detector voltage of $+1.7 \mathrm{kV}$, with acquisition mode selected ion monitoring of the appropriate molecular weights of the test compounds. The curved desolvation line temperature was $250^{\circ} \mathrm{C}$, heat block temperature was $200{ }^{\circ} \mathrm{C}$, and neutralizing gas flow was $1.5 \mathrm{~L} / \mathrm{min}$. Samples were injected by an autosampler. Electrospray ionization was operated in positive and negative modes.

\subsection{Molecular Modeling Studies}

All molecular modeling studies were performed with Discovery Studio 3.0 (Accelrys, San Diego, USA). The crystal structures of tubulin in complex with DAMA-colchicine (PDB: 1SA0) and with TN16 (PDB: 3HKD) were downloaded from the RCSB Protein Data Bank (http://www.rcsb.org/pdb) for possible use in the modeling study. We selected the structure 1SA0 as our modeling system. CDOCKER was used to evaluate and predict in silico binding free energy of the inhibitors and automated docking. The protein protocol was 
prepared by several operations, including standardization of atom names, insertion of missing atoms in residues and removal of alternate conformations, insertion of missing loop regions based on SEQRES data, optimization of short and medium size loop regions with Looper Algorithm, minimization of remaining loop regions, calculation of $\mathrm{pK}$, and protonation of the structure. The receptor model was typed with the CHARMm force field. A binding sphere with radius of $8.5 \AA$ A was defined through the original ligand (DAMAcolchicine) as the binding site for the study. The docking protocol employed total ligand flexibility, and the final ligand conformations were determined by the simulated annealing molecular dynamics search method set to a variable number of trial runs. The docked ligands (4i, $\mathbf{5 f}$, and $\mathbf{6 d}$ ) were further refined using in situ ligand minimization with the Smart Minimizer algorithm by standard parameters. The ligand and its surrounding residues within the above defined sphere were allowed to move freely during the minimization, while the outer atoms were frozen. The implicit solvent model of Generalized Born with Molecular Volume (GBMV) was also used to calculate the binding energies.

\section{Supplementary Material}

Refer to Web version on PubMed Central for supplementary material.

\section{Acknowledgments}

This investigation was supported by Grants 81120108022 and 30930106 from the Natural Science Foundation of China (NSFC) awarded to Dr. Lan Xie and NIH Grant CA17625-32 from the National Cancer Institute awarded to Dr. K. H. Lee. This study was also supported in part by the Taiwan Department of Health, China Medical University Hospital Cancer Research Center of Excellence (DOH100-TD-C-111-005).

\section{References}

1. Jordan MA, Wilson L. Microtubules as a target for anticancer drugs. Nat. Rev. Cancer. 2004; 4:253-265. [PubMed: 15057285]

2. Dumontet C, Jordan MA. Microtubule-binding agents: a dynamic field of cancer therapeutics. Nat. Rev. Drug Discov. 2010; 9:790-803. [PubMed: 20885410]

3. Sengupta S, Thomas SA. Drug target interaction of tubulin-binding drugs in cancer therapy. Expert Rev. Anticancer Ther. 2006; 6:1433-1447. [PubMed: 17069528]

4. Siemann DW. The unique characteristics of tumor vasculature and preclinical evidence for its selective disruption by tumor-vascular disrupting agents. Cancer Treat. Rev. 2011; 37:63-74. [PubMed: 20570444]

5. Mason RP, Zhao D, Liu L, Trawick L, Pinney KG. A perspective on vascular disrupting agents that interact with tubulin: preclinical tumor imaging and biological assessment. Integr. Biol. 2011; 3:375-387.

6. Wang XF, Tian XT, Ohkoshi E, Qin BJ, Liu YN, Wu PC, Hung HY, Hour MJ, Qian K, Huang R, Bastow KF, Janzen WP, Jin J, Morris-Natschke SL, Lee KH, Xie L. Design and synthesis of diarylamines and diarylethers as cytotoxic antitumor agents. Bioorg. Med. Chem. Lett. 2012; 22:6224-6228. [PubMed: 22932313]

7. Wang XF, Ohkoshi E, Wang SB, Hamel E, Bastow KF, Morris-Natschke SL, Lee KH, Xie L. Synthesis and biological evaluation of $\mathrm{N}$-alkyl- $\mathrm{N}$-(4-methoxyphenyl)pyridin-2- amines as a new class of tubulin polymerization inhibitors. Bioorg. Med. Chem. 2013; 21:632-642. [PubMed: 23274123]

8. Blagg, J. Structure-activity relationships for in vitro and in vivo toxicity. In: Anthony, W., editor. Annu. Rep. Med. Chem. Vol. 41. Academic Press; 2006. p. 353-368.

9. Kerns, EH.; Di, L. In drug-like properties: concepts, structure design and methods. Academic Press; San Diego: 2008. Metabolic stability; p. 151 
10. Mei X, August AT, Wolf C. Regioselective copper-catalyzed amination of chlorobenzoic acids: synthesis and solid-state structures of $N$-aryl anthranilic acid derivatives. J. Org. Chem. 2006; 71:142-149. [PubMed: 16388629]

11. Jensen TA, Liang X, Tanner D, Skjaerbaek N. Rapid and efficient microwave-assisted synthesis of aryl aminobenzophenones using Pd-catalyzed amination. J. Org. Chem. 2004; 69:4936-4947. [PubMed: 15255719]

12. Onnis V, Cocco MT, Lilliu V, Congiu C. Synthesis and evaluation of antitumor activity of ester and amide derivatives of 2-arylamino-6-trifluoromethyl-3-pyridinecarboxylic acids. Bioorg. Med. Chem. 2008; 16:2367-2378. [PubMed: 18065230]

13. Nose A, Kudo T. Reduction of heterocyclic compounds. II. Reducation of heterocyclic compounds with sodium borohydride-transition metal salt systems. Chem. Pharm. Bull. 1984; 32:2421-2425.

14. Perez-Sayans M, Somoza-Martin JM, Barros-Angueira F, Diz PG, Rey JM, Garcia-Garcia A. Multidrug resistance in oral squamous cell carcinoma: The role of vacuolar ATPases. Cancer Lett. 2010; 295:135-143. [PubMed: 20418015]

15. Hung HY, Ohkoshi E, Goto M, Bastow KF, Nakagawa-Goto K, Lee KH. Antitumor agents. 293. Nontoxic dimethyl-4,4'-dimethoxy-5,6,5',6'-dimethylenedioxylbiphenyl-2,2'- dicarboxylate (DDB) analogues chemosensitize multidrug-resistant cancer cells to clinical anticancer drugs. J. Med. Chem. 2012; 55:5413-5424. [PubMed: 22612652]

16. Rubinstein LV, Shoemaker RH, Paull RM, Tosini S, Skehan P, Scudiero DA, Mpnks A, Boyd MR. Comparison of in vitro anticancer-drug-screening data generated with a tetrazolium assay versus a protein assay against a diverse panel of human tumor cell lines. J. Natl. Cancer Inst. 1990; 82:1113-1117. [PubMed: 2359137]

17. Ravelli RBG, Gigant B, Curmi PA, Jourdain I, Lachkar S, Sobel A, Knossow M. Insight into tubulin regulation from a complex with colchicine and a stathmin-like domain. Nature. 2004; 428:198-202. [PubMed: 15014504]

18. Dorleans A, Gigant B, Ravelli RBG, Mailliet P, Mikol V, Knossow M. Variations in the colchicine-binding domain provide insight into the structural switch of tubulin. PNAS. 2009; 106:13775-13779. [PubMed: 19666559]

19. Gangjee A, Zhao Y, Lin L, Raghavan S, Roberts EG, Risinger AL, Hamel E, Mooberry SL. Synthesis and discovery of water-soluble microtubule targeting agents that binding to the colchicine site on tubulin and circumvent Pgp medicated resistance. J. Med. Chem. 2010; 53:8116-8128. [PubMed: 20973488]

20. Sun LQ, Zhu L, Qian K, Qin B, Huang L, Chen CH, Lee KH, Xie L. Design, synthesis, and preclinical evaluations of novel 4-substituted 1,5-diarylanilines as potent HIV-1 non-nucleoside reverse transcriptase inhibitor (NNRTI) drug candidates. J. Med. Chem. 2012; 55:7219-7229. [PubMed: 22856541]

21. Cai SX. Small molecule vascular disrupting agents: potential new drugs for cancer treatment. AntiCancer Drugs. 2007; 2:79-101.

22. Boyd, MR. Status of the NCI preclinical antitumor drug discovery screen. In: Devita, VT.; Hellman, S.; Rosenberg, SA., editors. Cancer: Principles and Practice of Oncology Updates. J.d B. Lippincott; Philadelphia: 1989. p. 1-12.

23. Monks A, Scudiero D, Skehan P, Shoemaker R, Paull K, Vistica D, Hose C, Langley J, Cronise P, Vaigro-Woiff A, Gray-Goodrich M, Campbell H, Mayo J, Boyd M. Feasibility of a high-flux anticancer drug screen using a diverse panel of cultured human tumor cell lines. J. Natl. Cancer Inst. 1991; 83:757-766. [PubMed: 2041050]

24. Houghton P, Fang R, Techatanawat I, Steventon G, Hylands PJ, Lee CC. The sulphorhodamine (SRB) assay and other approaches to testing plant extracts and derived compounds for activities related to reputed anticancer activity. Methods. 2007; 42:377-387. [PubMed: 17560325]

25. Hamel E. Evaluation of antimitotic agents by quantitative comparisons of their effects on the polymerization of purified tubulin. Cell Biochem. Biophys. 2003; 38:1-22. [PubMed: 12663938]

26. Lin CM, Ho HH, Pettit GR, Hamel E. Antimitotic natural products combretastatin A-4 and combretastatin A-2: studies on the mechanism of their inhibition of the binding of colchicine to tubulin. Biochemistry. 1989; 28:6984-6991. [PubMed: 2819042] 


\section{HIGHLIGHTS}

New $N$-aryl-6-methoxy-1,2,3,4-tetrahydroquinolines inhibited tubulin polymerization. Compound 6d significantly inhibited colchicine binding $(99 \%, 5 \mu \mathrm{M} ; 95 \%, 1 \mu \mathrm{M})$. Compound 6d was more potent than anticancer drug paclitaxel ( $\left.\mathrm{GI}_{50} 1.5-1.7 \mathrm{nM}\right)$. A fused aromatic ring, such as quinoline and quinazoline, improved molecular potency A feasible torsional angle between the two aryl rings is important for high potency. 

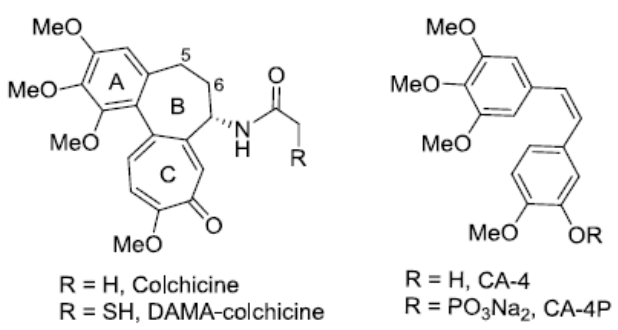

$$
\begin{aligned}
& \mathrm{R}=\mathrm{H}, \mathrm{CA}-4 \\
& \mathrm{R}=\mathrm{PO}_{3} \mathrm{Na}_{2}, \mathrm{CA}-4 \mathrm{P} \text { (phase II/III) ZD6126 (phase I) }
\end{aligned}
$$

Fig. 1.

Colchicine, DAMA-colchicine, and clinical trial candidates targeted at the colchicine site of tubulin. 


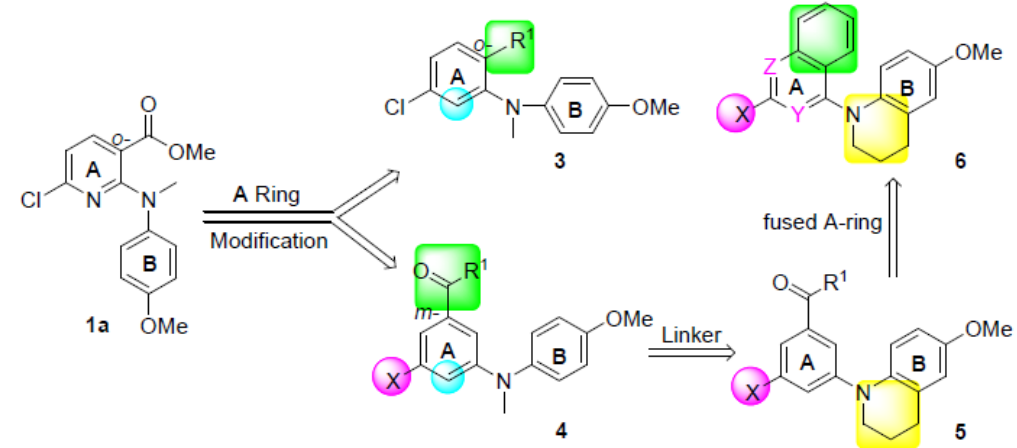

Fig. 2.

Modification strategies and new target compounds 3-6 series 


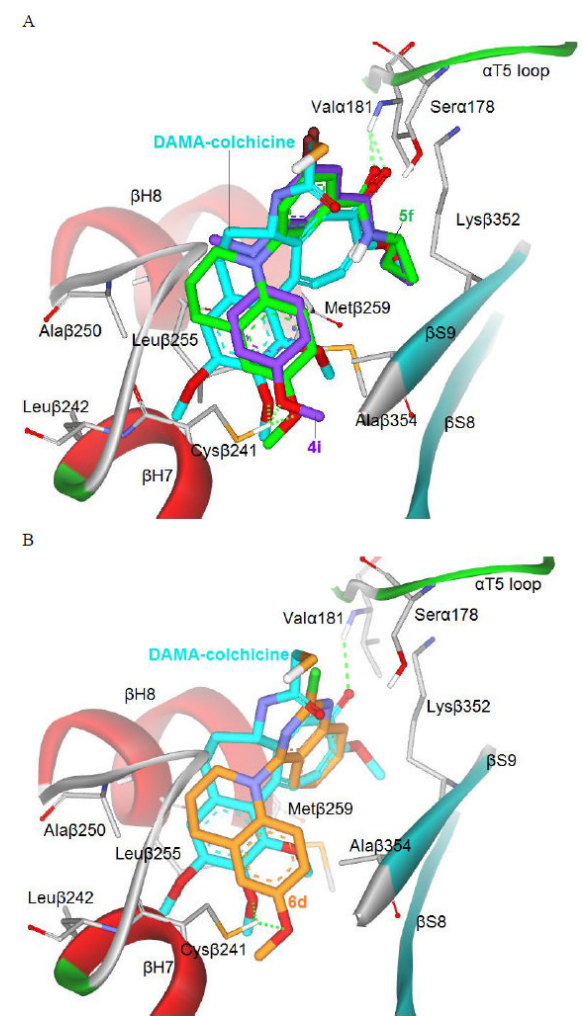

Fig. 3.

(A) Predicted modes for 4i (purple stick) and $\mathbf{5 f}$ (green) binding with tubulin (PDB code: 1SA0), and overlapping with DAMA-colchicine (cyan, the native ligand of 1SA0); (B) Superimposition of docked compound 6d (orange) with DAMA-colchicine (cyan). Surrounding amino acid side chains are shown in gray stick format and labeled. Hydrogen bonds are shown by green dashed lines, and the distance between ligands and protein is less than $3 \AA$. 


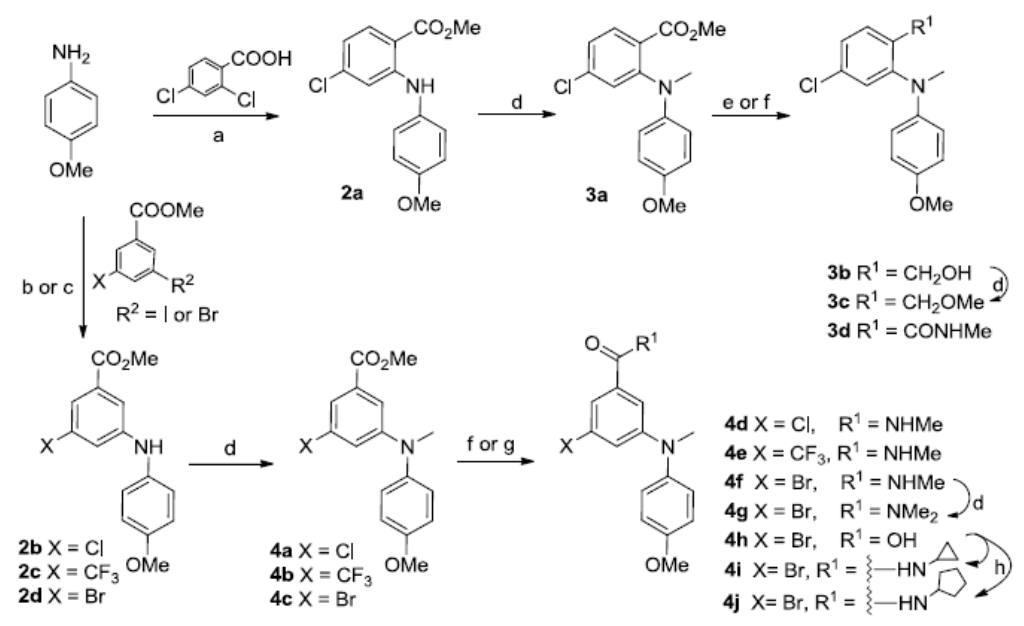

Scheme 1.

a) i. $\mathrm{K}_{2} \mathrm{CO}_{3}, \mathrm{Cu}, \mathrm{Cu}_{2} \mathrm{O}, 2$-ethoxyethanol, $\mathrm{N}_{2}, 130{ }^{\circ} \mathrm{C}, 24 \mathrm{~h}, 67 \%$; ii. DMF-DMA in toluene, reflux, $2 \mathrm{~h}, 85 \%$; b) i. $\mathrm{Cs}_{2} \mathrm{CO}_{3}, \mathrm{Pd}(\mathrm{OAc})_{2}$, X-Phos, Celite, toluene/ $t-\mathrm{BuOH}, \mathrm{N}_{2}, \mathrm{mw}$, 120-150 ${ }^{\circ} \mathrm{C}, 30-60 \mathrm{~min}, 74 \%$ for $\mathbf{2 b}$ and $\left.\mathbf{2 c} ; \mathrm{c}\right) \mathrm{Cs}_{2} \mathrm{CO}_{3}, \mathrm{Pd}(\mathrm{OAc})_{2}$, BINAP, toluene, $\mathrm{N}_{2}$, reflux $12 \mathrm{~h}, 64 \%$ for $2 \mathrm{~d}$; d) $\mathrm{MeI} / \mathrm{NaH}\left(60 \%\right.$ oil suspension), $0{ }^{\circ} \mathrm{C}, 1 \mathrm{~h}$; e) $\mathrm{LiAlH}_{4} / \mathrm{THF}, 0{ }^{\circ} \mathrm{C}$, $1 \mathrm{~h}, 97 \%$; f) $30 \% \mathrm{NH}_{2} \mathrm{Me} / \mathrm{MeOH}, 100-120{ }^{\circ} \mathrm{C}$, mw, 1-2 h for 3d, 4d-f; g) MeOH/THF, $3 \mathrm{~N}$ $\mathrm{NaOH}$ aq, reflux, 5 h, $90 \%$ for $\mathbf{4 h}$; h) EDCI, HOBt, cyclopropylamine or cyclopentylamine, $\mathrm{CH}_{2} \mathrm{Cl}_{2}, \mathrm{rt}, 24 \mathrm{~h}$ for $\mathbf{4} \mathbf{i}$ and $\mathbf{4 j}$. 


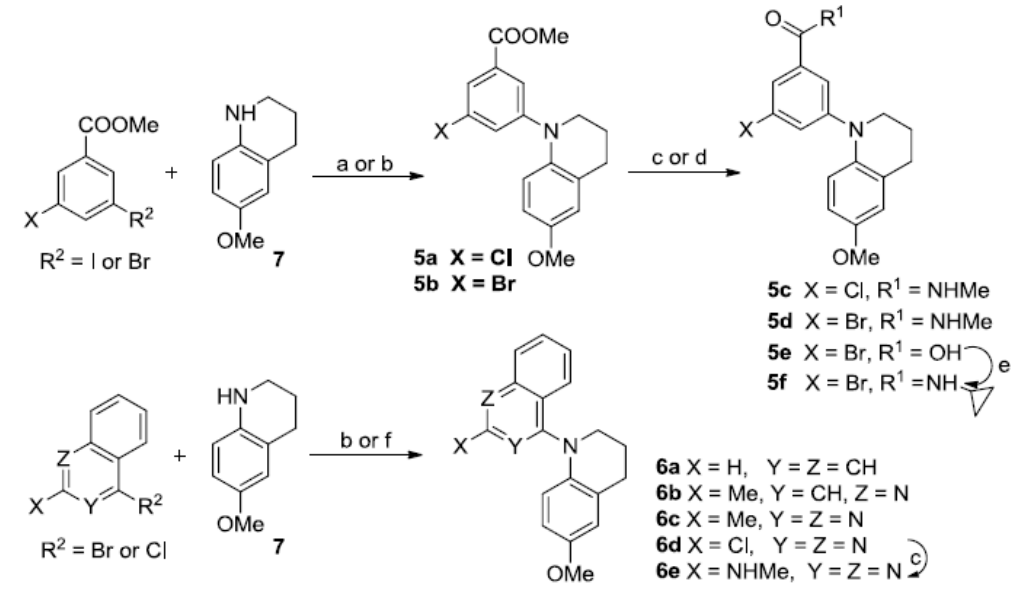

Scheme 2.

a) $\mathrm{Cs}_{2} \mathrm{CO}_{3}, \mathrm{Pd}(\mathrm{OAc})_{2}$, X-Phos, Celite, $\mathrm{N}_{2}, \mathrm{mw}, 120{ }^{\circ} \mathrm{C}, 30 \mathrm{~min}, 77 \%$ for $\mathbf{5 a}$; b) $\mathrm{Cs}_{2} \mathrm{CO}_{3}$, $\mathrm{Pd}(\mathrm{OAc})_{2}$, BINAP, toluene, $\mathrm{N}_{2}$, reflux, $12 \mathrm{~h}, 68-75 \%$ for $\mathbf{5 b}$ and $\mathbf{6 a - 6 b}$; c) $30 \% \mathrm{NH}_{2} \mathrm{Me} /$ $\mathrm{MeOH}, 100{ }^{\circ} \mathrm{C}$, mw, $1 \mathrm{~h}$ for $\mathbf{5 c}, \mathbf{5 d}$, and $\mathbf{6 e}$; d) MeOH/THF, $3 \mathrm{~N} \mathrm{NaOH}$ aq, reflux, $5 \mathrm{~h}, 82 \%$ for 5e; e) EDCI, $\mathrm{HOBt}$, cyclopropylamine, $\mathrm{CH}_{2} \mathrm{Cl}_{2}$, rt, 24 h, $90 \%$; f) $\mathrm{NaHCO}_{3} / \mathrm{EtOH}$, reflux, $3 \mathrm{~h}$ for $\mathbf{6 c}$ and $\mathbf{6 d}$. 
Table 1

Cytotoxicity of series $\mathbf{3 - 5}$ compounds against human tumor cell lines (HTCL)<smiles>COc1ccc(N(C)c2nc(Cl)ccc2C(C)=O)cc1</smiles>

$1 \mathrm{a}$<smiles>[X]c1ccc(N(C)c2ccc(OC)cc2)c([R])c1</smiles><smiles>[R]c1cccc(N2CCCc3cc(OC)ccc32)c1</smiles>

\begin{tabular}{|c|c|c|c|c|c|c|}
\hline & \multirow{2}{*}{$\mathbf{x}$} & \multirow{2}{*}{$\mathbf{R}^{1}$} & \multicolumn{4}{|c|}{$\mathbf{G I}_{50}(\mu \mathrm{M})^{a}$} \\
\hline & & & A549 & KB & KBvin & DU145 \\
\hline 1a & & & $0.23 \pm 0.01$ & $0.26 \pm 0.04$ & $0.20 \pm 0.03$ & $0.21 \pm 0.04$ \\
\hline 3a & $\mathrm{Cl}$ & $o$-COOMe & $3.36 \pm 0.49$ & $1.98 \pm 0.37$ & $1.89 \pm 0.17$ & $1.68 \pm 0.04$ \\
\hline $\mathbf{3 b}$ & $\mathrm{Cl}$ & $o-\mathrm{CH}_{2} \mathrm{OH}$ & $21.7 \pm 2.53$ & $19.5 \pm 1.33$ & $18.1 \pm 2.24$ & $16.0 \pm 2.73$ \\
\hline $3 c$ & $\mathrm{Cl}$ & $o-\mathrm{CH}_{2} \mathrm{OMe}$ & $4.53 \pm 0.84$ & $5.24 \pm 0.42$ & $2.85 \pm 0.62$ & $3.13 \pm 0.35$ \\
\hline $3 d$ & $\mathrm{Cl}$ & $o$-CONHMe & $43.2 \pm 4.81$ & $188 \pm 33.8$ & $61.0 \pm 5.13$ & $98.9 \pm 4.22$ \\
\hline $4 a$ & $\mathrm{Cl}$ & $m$-COOMe & $1.60 \pm 0.36$ & $1.61 \pm 0.08$ & $1.57 \pm 0.10$ & $1.46 \pm 0.16$ \\
\hline $4 b$ & $\mathrm{CF}_{3}$ & $m$-COOMe & $15.1 \pm 2.6$ & $13.5 \pm 1.21$ & $13.1 \pm 1.41$ & $11.5 \pm 1.71$ \\
\hline $4 c$ & $\mathrm{Br}$ & $m$-COOMe & $1.24 \pm 0.34$ & $1.36 \pm 0.17$ & $1.20 \pm 0.39$ & $0.97 \pm 0.08$ \\
\hline $4 d$ & $\mathrm{Cl}$ & $m$-CONHMe & $0.27 \pm 0.01$ & $0.30 \pm 0.04$ & $0.23 \pm 0.04$ & $0.23 \pm 0.03$ \\
\hline $4 e$ & $\mathrm{CF}_{3}$ & $m$-CONHMe & $14.7 \pm 2.23$ & $12.3 \pm 1.72$ & $12.6 \pm 1.81$ & $11.9 \pm 2.20$ \\
\hline $4 f$ & $\mathrm{Br}$ & $m$-CONHMe & $0.25 \pm 0.07$ & $0.21 \pm 0.03$ & $0.14 \pm 0.01$ & $0.16 \pm 0.07$ \\
\hline $4 \mathrm{~g}$ & $\mathrm{Br}$ & $m-\mathrm{CONMe}_{2}$ & $2.83 \pm 0.59$ & $6.52 \pm 1.16$ & $2.38 \pm 0.37$ & $3.34 \pm 0.54$ \\
\hline $4 \mathrm{~h}$ & $\mathrm{Br}$ & $m-\mathrm{COOH}$ & $\mathrm{NA}^{b}$ & NA & NA & $\mathrm{NA}$ \\
\hline $4 i$ & $\mathrm{Br}$ & & $0.17 \pm 0.02$ & $0.17 \pm 0.02$ & $0.17 \pm 0.02$ & $0.17 \pm 0.02$ \\
\hline $4 \mathbf{j}$ & $\mathrm{Br}$ & & $0.12 \pm 0.02$ & $0.12 \pm 0.01$ & $0.12 \pm 0.01$ & $0.11 \pm 0.01$ \\
\hline $5 a$ & $\mathrm{Cl}$ & $m$-COOMe & $2.23 \pm 0.23$ & $2.33 \pm 0.47$ & $1.78 \pm 0.31$ & $1.51 \pm 0.46$ \\
\hline $5 \mathbf{b}$ & $\mathrm{Br}$ & $m$-COOMe & $1.12 \pm 0.14$ & $1.37 \pm 0.31$ & $1.27 \pm 0.22$ & $1.28 \pm 0.25$ \\
\hline $5 \mathrm{c}$ & $\mathrm{Cl}$ & $m$-CONHMe & $0.74 \pm 0.08$ & $1.04 \pm 0.11$ & $0.43 \pm 0.03$ & $1.02 \pm 0.10$ \\
\hline $5 d$ & $\mathrm{Br}$ & $m$-CONHMe & $0.37 \pm 0.08$ & $0.63 \pm 0.34$ & $0.93 \pm 0.02$ & $0.56 \pm 0.09$ \\
\hline $5 f$ & $\mathrm{Br}$ & & $0.17 \pm 0.01$ & $0.16 \pm 0.03$ & $0.19 \pm 0.01$ & $0.15 \pm 0.02$ \\
\hline
\end{tabular}


<smiles>COc1ccc(N(C)c2nc(Cl)ccc2C(C)=O)cc1</smiles>

1a
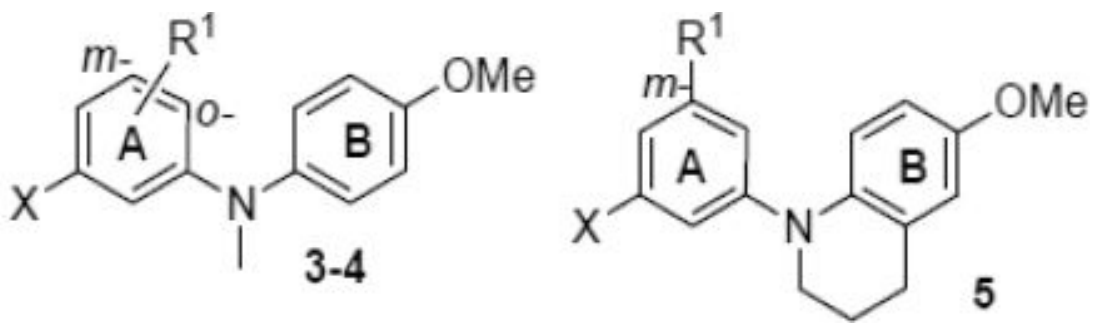

\begin{tabular}{|c|c|c|c|c|c|}
\hline \multirow{2}{*}{$\mathbf{X}$} & \multirow{2}{*}{$\mathbf{R}^{1}$} & \multicolumn{4}{|c|}{$\mathbf{G I}_{50}(\mu \mathbf{M})^{a}$} \\
\hline & & A549 & $\mathbf{K B}$ & KBvin & DU145 \\
\hline Paclitaxel $^{c}$ & & $0.0076 \pm 0.0017$ & $0.0064 \pm 0.0014$ & $1.21 \pm 0.19$ & $0.006 \pm 0.001$ \\
\hline
\end{tabular}

${ }^{a}$ Concentration of compound that inhibits $50 \%$ human tumor cell growth, presented as mean \pm standard deviation (SD), performed at least in triplicate.

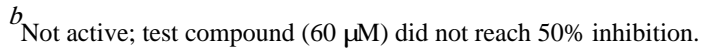

${ }^{c}$ Positive control. 
Table 2

Cytotoxicity of $\mathbf{6}$ series against human tumor cell lines

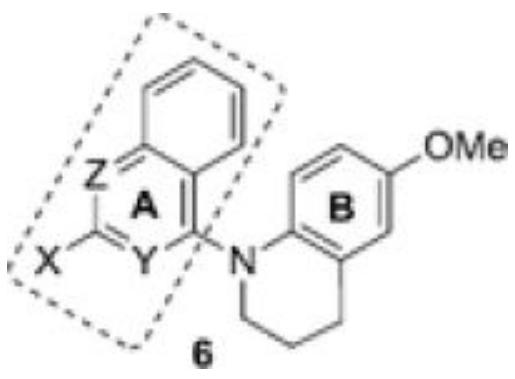

\begin{tabular}{|c|c|c|c|c|c|c|c|}
\hline & \multicolumn{3}{|c|}{ Fused A-ring } & \multicolumn{4}{|c|}{$\mathbf{G I}_{50}(\mu \mathrm{M})^{a}$} \\
\hline & $\mathbf{x}$ & $\mathbf{Y}$ & $\mathbf{Z}$ & A549 & KB & KBvin & DU145 \\
\hline $6 a$ & $\mathrm{H}$ & $\mathrm{CH}$ & $\mathrm{CH}$ & $17.8 \pm 2.6$ & $15.6 \pm 1.3$ & $17.6 \pm 2.5$ & $14.8 \pm 1.7$ \\
\hline $6 b$ & $\mathrm{Me}$ & $\mathrm{CH}$ & $\mathrm{N}$ & $0.045 \pm 0.008$ & $0.091 \pm 0.009$ & $0.055 \pm 0.010$ & $0.038 \pm 0.008$ \\
\hline $6 c$ & $\mathrm{Me}$ & $\mathrm{N}$ & $\mathrm{N}$ & $0.018 \pm 0.001$ & $0.011 \pm 0.001$ & $0.018 \pm 0.004$ & $0.015 \pm 0.005$ \\
\hline 6d & $\mathrm{Cl}$ & $\mathrm{N}$ & $\mathrm{N}$ & $0.0017 \pm 0.0003$ & $0.0017 \pm 0.0008$ & $0.0017 \pm 0.0003$ & $0.0015 \pm 0.0003$ \\
\hline $6 e$ & $\mathrm{NHMe}$ & $\mathrm{N}$ & $\mathrm{N}$ & $0.027 \pm 0.005$ & $0.025 \pm 0.002$ & $0.029 \pm 0.005$ & $0.023 \pm 0.003$ \\
\hline \multicolumn{4}{|c|}{ Paclitaxel $^{b}$} & $0.0076 \pm 0.0017$ & $0.0064 \pm 0.0014$ & $1.21 \pm 0.19$ & $0.006 \pm 0.001$ \\
\hline
\end{tabular}

${ }^{a}$ Concentration of compound that inhibits 50\% human tumor cell growth

$b_{\text {Positive control. }}$ 


\section{Table 3}

Inhibition of tubulin polymerization ${ }^{a}$ and colchicine binding to tubulin ${ }^{b}$

\begin{tabular}{lcll}
\hline Compound & $\begin{array}{c}\text { Inhibition of tubulin assembly } \\
\mathbf{I C}_{\mathbf{5 0}}(\boldsymbol{\mu M}) \pm \mathbf{S D}\end{array}$ & \multicolumn{2}{c}{$\begin{array}{c}\text { Inhibition of colchicine binding } \\
(\boldsymbol{\%}) \text { inhibition } \pm \mathbf{S D}\end{array}$} \\
\cline { 3 - 4 } & & at $\mathbf{5} \boldsymbol{\mu \mathbf { M }}$ & at $\mathbf{1} \boldsymbol{\mu M}$ \\
\hline $\mathbf{4 f}$ & $2.2 \pm 0.2$ & $71 \pm 0.3$ & $\mathrm{ND}^{c}$ \\
$\mathbf{4 i}$ & $1.6 \pm 0.04$ & $69 \pm 3.0$ & $\mathrm{ND}$ \\
$\mathbf{5 f}$ & $1.0 \pm 0.1$ & $75 \pm 1.0$ & $\mathrm{ND}$ \\
$\mathbf{6 b}$ & $1.0 \pm 0.1$ & $87 \pm 2.0$ & $61 \pm 2.0$ \\
$\mathbf{6 c}$ & $1.0 \pm 0.1$ & $98 \pm 0.2$ & $89 \pm 2.0$ \\
$\mathbf{6 d}$ & $0.93 \pm 0.04$ & $99 \pm 0.6$ & $95 \pm 0.7$ \\
$\mathbf{6 e}$ & $0.92 \pm 0.06$ & $95 \pm 0.2$ & $76 \pm 0.1$ \\
\hline $\mathbf{C A 4}{ }^{d}$ & $0.96 \pm 0.07$ & $98 \pm 0.6$ & $90 \pm 0.2$ \\
\hline
\end{tabular}

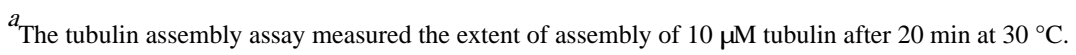

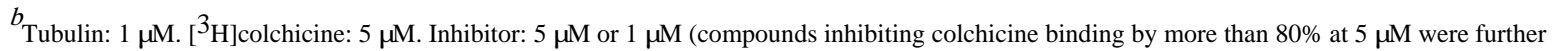
tested). Incubation was performed for $10 \mathrm{~min}$ at $37^{\circ} \mathrm{C}$.

$c_{\text {Not determined. }}$

$d_{\text {reference compound is a drug candidate in phase II/III clinical trials. }}$ 
Table 4

Physicochemical parameters of selected compounds

\begin{tabular}{cccc}
\hline \multirow{2}{*}{ Compound } & \multicolumn{2}{c}{ at $\mathbf{p H} \mathbf{7 . 4}$} & \multicolumn{2}{c}{$\begin{array}{c}\text { Human liver microsome } \\
\mathbf{t}_{\mathbf{1} / \mathbf{2}} \mathbf{\text { min }}\end{array}$} \\
\cline { 2 - 4 } & $\begin{array}{c}\text { Water Solubility } \\
(\boldsymbol{\mu g} \mathbf{g} \mathbf{m L})\end{array}$ & $\mathbf{L o g} \mathbf{P}$ & $\mathrm{ND}^{c}$ \\
$\mathbf{4 f}$ & $0.81 \pm 0.01$ & $4.02 \pm 0.11$ & $\mathrm{ND}$ \\
$\mathbf{4 i}$ & $0.16 \pm 0.03$ & $4.33 \pm 0.12$ & $\mathrm{ND}$ \\
$\mathbf{5 f}$ & $0.26 \pm 0.05$ & $4.75 \pm 0.09$ & 7.89 \\
$\mathbf{6 b}$ & $3.21 \pm 0.60$ & $3.98 \pm 0.02$ & 25.19 \\
$\mathbf{6 c}$ & $7.67 \pm 0.40$ & $3.65 \pm 0.03$ & 10.59 \\
$\mathbf{6 d}$ & $0.45 \pm 0.06$ & $4.13 \pm 0.05$ & 25.97 \\
\hline 6e & $7.21 \pm 0.06$ & $1.07 \pm 0.21$ & 40.82 \\
\hline Propranolol $^{a}$ & & & 21.14 \\
\hline Terfenadine $^{b}$ & & & \\
\hline
\end{tabular}

Data presented as mean from three separate experiments with or without \pm standard deviation (SD).

${ }^{a}$ Propranolol has moderate metabolic stability with $\mathrm{t} 1 / 2$ of $3-5 \mathrm{~h}$ in vivo;

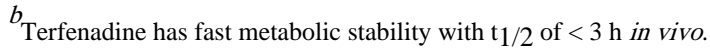

${ }^{c}$ Not determined. 